\title{
Diversity and composition of Amazonian moths in primary, secondary and plantation forests
}

\author{
Joseph Hawes*1, Catarina da Silva Motta†, William L. Overalł, Jos Barlow§, \\ Toby A. Gardner\# and Carlos A. Peres*
}

\author{
* School of Environmental Sciences, University of East Anglia, Norwich NR4 7TJ, UK \\ $\dagger$ Departamento de Entomologia, Instituto Nacional de Pesquisas da Amazônia (INPA), Caixa Postal 478, Manaus, AM 69011-970, Brazil \\ $\ddagger$ Departamento de Entomologia, Museu Paraense Emílio Goeldi (MPEG), Av. Perimetral 1901, Bairro Terra Firme, Belém, PA 66077-530, Brazil \\ $\S$ Lancaster Environment Centre, Lancaster University, Lancaster LA1 4YW, UK \\ \# Departamento de Biologia, Universidade Federal de Lavras, Lavras, Minas Gerais 37200-000, Brazil \\ (Accepted 19 February 2009)
}

\begin{abstract}
The response of tropical fauna to landscape-level habitat change is poorly understood. Increased conversion of native primary forest to alternative land-uses, including secondary forest and exotic tree plantations, highlights the importance of assessing diversity patterns within these forest types. We sampled 1848 moths from 335 species of Arctiidae, Saturniidae and Sphingidae, over a total of 30 trap-nights. Sampling was conducted during the wet season 2005, using three light-traps at 15 sites within areas of primary forest, secondary forest and Eucalyptus urograndis plantations in northern Brazilian Amazonia. The Jari study region provides one of the best opportunities to investigate the ecological consequences of land-use change, and this study is one of the first to examine patterns of diversity for a neotropical moth assemblage in a human-dominated landscape in lowland Amazonia. We found that the three moth families responded consistently to disturbance in terms of abundance and community structure but variably in terms of species richness, in a manner apparently supporting a life-history hypothesis. Our results suggest that secondary forests and Eucalyptus plantations can support a substantial level of moth diversity but also show that these forest types hold assemblages with significantly distinct community structures and composition from primary forest. In addition, the ability of these converted land-uses to support primary forest species may be enhanced by proximity to surrounding primary forest, an issue which requires consideration when assessing the diversity and composition of mobile taxa in human-dominated landscapes.
\end{abstract}

Key Words: Arctiidae, Brazil, human-dominated landscapes, land-use change, Lepidoptera, Saturnidae, Sphingidae

\section{INTRODUCTION}

The ecological consequences of land-use change vary considerably for different taxa, as particular species traits interact differently with the disturbed environment (Daily 2001, Koh et al. 2004). A clear understanding of these consequences is currently lacking for both secondary (Brook et al. 2006, Gardner et al. 2007) and plantation forests (Hartley 2002, Lindenmayer \& Hobbs 2004), which are both increasing in importance within tropical forest landscapes (Evans \& Turnbull 2004, Neeff et al. 2006).

While most studies to date have focused on charismatic indicator or flagship groups such as birds and mammals,

\footnotetext{
*Corresponding author. Email: j.hawes@uea.ac.uk
}

attention is now expanding to a wider range of taxa (Barlow et al. 2007, Gardner et al. 2008). Insects make an enormous contribution to both tropical diversity (Lewinsohn et al. 2005) and ecosystem functioning (Wilson 1987), and moths are one of the groups playing a central role in numerous ecosystem processes as prey, herbivores and pollinators (Barlow \& Woiwod 1989, Janzen 1987).

Relatively few studies of tropical moth faunas have been conducted in the neotropics (Brehm et al. 2003, Hilt et al. 2006, Ricketts et al. 2001) despite higher species richness in this region than elsewhere in the tropics (Hilt \& Fiedler 2005). There is also a current lack of understanding regarding the relative importance of local forest type versus landscape features of the wider countryside in determining patterns of diversity (but see 


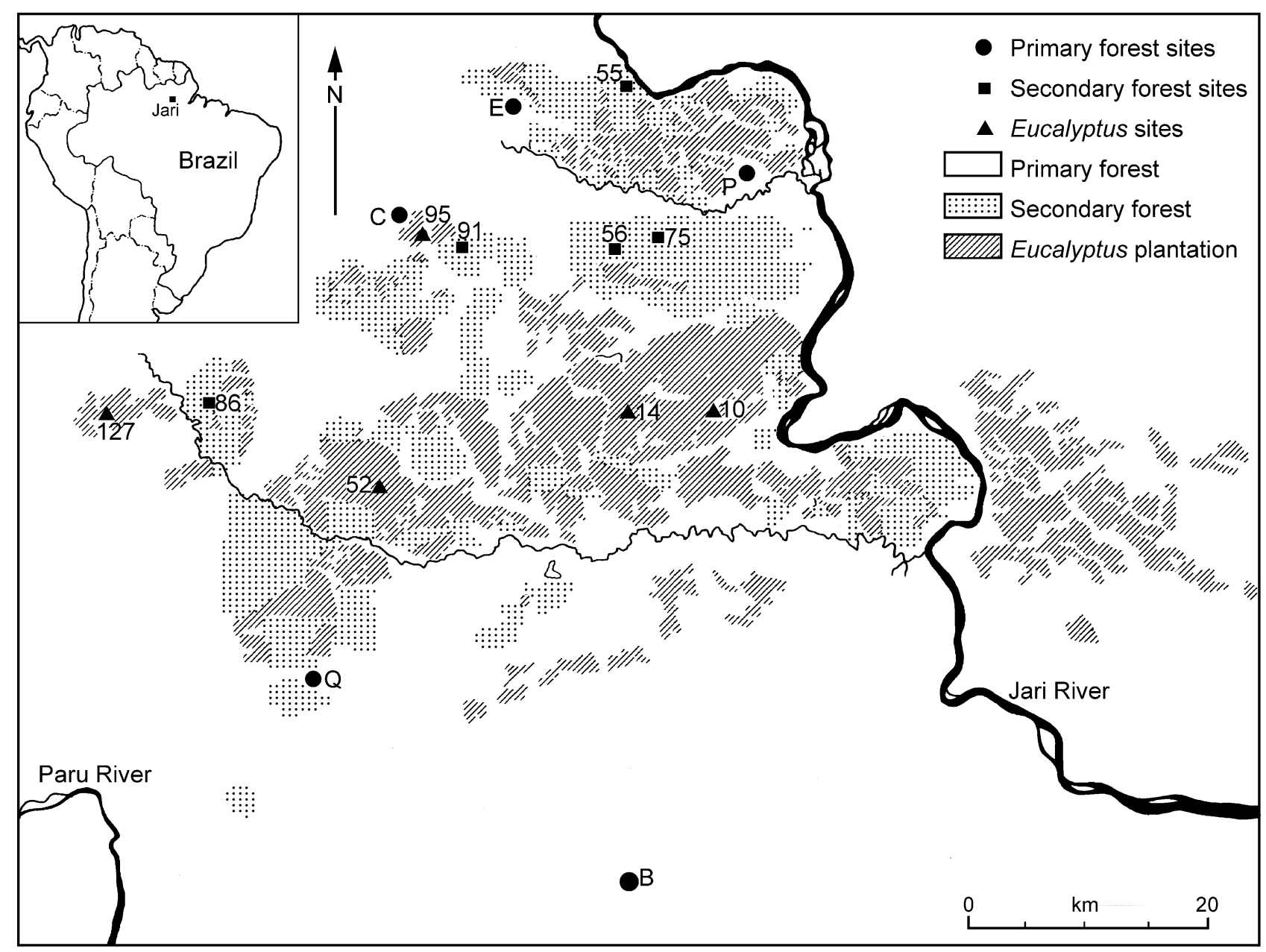

Figure 1. Map of the Jari landholding in the northern Brazilian Amazon and locations of the 15 sites within areas of primary forest, secondary forest and Eucalyptus urograndis plantations where moth sampling was carried out between April and May 2005. Labels refer to the individual sites listed in Table 1.

Ricketts et al. 2001). This study is one of the first to examine the diversity patterns of lowland Amazonian moth assemblages in a human-dominated landscape including primary, secondary and plantation forests.

We sampled three families differing in their ecology and life-histories (Hilt \& Fiedler 2006, Janzen 1984): the large-bodied emperor moths (Saturniidae) and hawk moths (Sphingidae), as well as the smaller-bodied tiger moths (Arctiidae). By assessing changes in abundance, species richness and community composition, this study examined the various effects of landscape-level disturbance on moth assemblages. We tested the a priori hypotheses that (1) disturbed forest types (secondary forests and Eucalyptus plantations) support distinct and less species-rich moth communities than primary forest, and (2) that responses to disturbance vary between moth families as a result of differences in life-history strategies e.g. mobile, long-lived taxa are predicted to persist better in disturbed forest types.

\section{METHODS}

\section{Study sites}

Sampling was conducted in the 1.7-Mha landholding of Jarí Celulose S.A., located on the border between the states of Amapá and Pará in northern Brazilian Amazonia $\left(0^{\circ} 53^{\prime} \mathrm{S}, 52^{\circ} 36^{\prime} \mathrm{W}\right.$; Figure 1$)$. The area was purchased in 1967, and about $10 \%$ of the land converted to exotic tree plantations. Current stands consist of Eucalyptus urograndis, while earlier plantations of Gmelina arborea and Pinus caribaea have mostly been cleared and abandoned. This process has resulted in a complex landscape mosaic of Eucalyptus plantations, with large tracts of regenerating secondary forest and relatively undisturbed primary forest. We sampled the moth community at 15 sites (Figure 1; Table 1), comprising five of each of the three forest types: (1) undisturbed primary forest; (2) even-aged native secondary forest 
Table 1. Selected details of the 15 light-trapping sites within primary (PF) and secondary forests (SF), and Eucalyptus plantations (EUC) in the Jari landscape. PF sites are part of large contiguous tracts of relatively undisturbed forest. Site names: $\mathrm{B}=\mathrm{Bituba}, \mathrm{C}=\mathrm{Castanhal}, \mathrm{E}=\mathrm{Estaçao}$, $\mathrm{P}=$ Pacanari, $\mathrm{Q}=$ Quaruba. Light-trap radius = distance at which light-trap is visible to the human eye, $\mathrm{PF}$ in 3-km-radius buffer $=$ proportion of a 3-km-radius area around each sampling site that contains PF. Significance was calculated with one-way ANOVAs; F $=$ F-ratio, ${ }^{* *}=\mathrm{P}<0.01$, superscript letters denote Tukey's HSD subsets.

\begin{tabular}{|c|c|c|c|c|c|c|c|c|c|}
\hline Habitat type & Site name & Area (ha) & Age (y) & Altitude (m) & $\begin{array}{c}\text { Tree basal } \\
\text { area } \\
\left(\mathrm{m}^{2} \mathrm{ha}^{-1}\right)\end{array}$ & $\begin{array}{c}\text { Mean } \\
\text { understorey } \\
\text { density (\%) }\end{array}$ & $\begin{array}{c}\text { Mean } \\
\text { canopy } \\
\text { cover }(\%)\end{array}$ & $\begin{array}{c}\text { Mean } \\
\text { light-trap } \\
\text { radius }(\mathrm{m})\end{array}$ & $\begin{array}{c}\text { PF in 3- } \\
\text { km-radius } \\
\text { buffer }(\%)\end{array}$ \\
\hline$\overline{\mathrm{PF}}$ & B & - & - & $250-275$ & 31.8 & 57.0 & 90.9 & 72.5 & 99.8 \\
\hline $\mathrm{PF}$ & $\mathrm{C}$ & - & - & 95 & 34.0 & 61.7 & 94.5 & 78.0 & 75.4 \\
\hline $\mathrm{PF}$ & $\mathrm{E}$ & - & - & 90 & 30.5 & 54.7 & 95.2 & 103.3 & 58.9 \\
\hline $\mathrm{PF}$ & $\mathrm{P}$ & - & - & 165 & 28.0 & 67.0 & 88.2 & 68.0 & 52.8 \\
\hline PF & Q & - & - & 100 & 25.7 & 66.0 & 93.2 & 88.7 & 55.0 \\
\hline $\mathrm{PF}$ & Mean & - & - & 142.5 & $30.0^{a}$ & $61.3^{b}$ & $92.4^{a}$ & $82.1^{b}$ & $68.4^{a}$ \\
\hline $\mathrm{SF}$ & 55 & 2.9 & 15 & 20 & 7.1 & 74.0 & 88.5 & 44.2 & 43.9 \\
\hline SF & 56 & 3.2 & 20 & 70 & 9.9 & 86.3 & 83.8 & 65.2 & 2.5 \\
\hline SF & 75 & 3.0 & 16 & 70 & 21.5 & 86.0 & 93.2 & 66.8 & 23.7 \\
\hline SF & 86 & 3.7 & 18 & 41 & 19.2 & 90.7 & 94.3 & 38.3 & 24.0 \\
\hline SF & 91 & 1.1 & 14 & 147 & 7.7 & 69.7 & 93.9 & 48.0 & 42.2 \\
\hline SF & Mean & 2.78 & 16.6 & 69.6 & $13.1^{b}$ & $81.3^{a}$ & $90.7^{a}$ & $52.5^{b}$ & $27.3^{b}$ \\
\hline EUC & 10 & 1.6 & 3.9 & 106 & 9.0 & 42.3 & 61.9 & 227.5 & 27.9 \\
\hline EUC & 14 & 1.3 & 3.7 & 131 & 8.8 & 24.3 & 63.7 & 268.0 & 7.8 \\
\hline EUC & 52 & 4.1 & 5.2 & 97 & 11.4 & 27.0 & 71.1 & 164.2 & 12.4 \\
\hline EUC & 95 & 0.6 & 3.9 & 139 & 17.7 & 45.7 & 75.9 & 155.0 & 61.2 \\
\hline EUC & 127 & 1.3 & 5.1 & 220 & 16.7 & 38.0 & 75.4 & 153.3 & 47.0 \\
\hline EUC & Mean & 1.78 & 4.36 & 138.6 & $12.7^{b}$ & $35.5^{c}$ & $69.6^{b}$ & $193.6^{a}$ & $31.3^{b}$ \\
\hline $\mathrm{F}$ & & & & & $19.7^{* *}$ & $40.0^{* *}$ & $34.1^{* *}$ & $27.4^{* *}$ & $6.5^{* *}$ \\
\hline
\end{tabular}

(14-20 y since abandonment); and (3) 4-5-y-old Eucalyptus plantation stands. Sites were selected to minimize age differences within each forest type, and to maximize their area (mean size of Eucalyptus and secondary forest blocks was 1687 ha (range $=574$ 3910 ha) and 2682 ha (range $=1079-3508$ ha), respectively) and spatial independence (mean distance between primary, secondary and Eucalyptus sites was $30 \mathrm{~km}($ range $=14-67 \mathrm{~km}), 9 \mathrm{~km}($ range $=4-44 \mathrm{~km})$ and $11 \mathrm{~km}(7-50 \mathrm{~km})$, respectively). Sampling was conducted between 1 April and 18 May 2005, during the wet season (January-June). Average annual rainfall at Jari is $2115 \mathrm{~mm}$, and the mean daily air temperature is $26^{\circ} \mathrm{C}$ (Coutinho \& Pires 1996).

\section{Moth sampling}

To sample moths we used a $2 \times 2$-m sheet trap design (Chey et al. 1997), which has the advantages over more standard light-traps (Intachat \& Woiwod 1999) of a selective catch, reduced damage to trapped individuals, and portability (Axmacher \& Fiedler 2004). We placed a standardized set of three light-traps at 200-m intervals along the line transects of each site. A 12-W UV blacklight tube was used at the central light-trap and a $160-\mathrm{W}$ mercury-vapour light bulb at the two outermost traps. For an overview of light-trapping feasibility see Beck \& Linsenmair (2006).
The effective 'radius of attraction' of light-traps (Beck \& Linsenmair 2006), is dependent upon sex and species identity (Baker \& Sadovy 1978) as well as light intensity and wavelength (Muirhead-Thomson 1991). While most evidence suggests an attraction radius of 50-200 m (Ricketts et al. 2001), Baker \& Sadovy (1978) report distances up to $500 \mathrm{~m}$. To minimize the capture of vagrants from surrounding forest types, all three lighttraps were located in the centre of each forest patch and at least $500 \mathrm{~m}$ from any edge with neighbouring forest types. The radial extent of light diffusion through each stand was also estimated for each trap by measuring the maximum distance in two diametrically opposite directions for which any light could be detected by eye.

Traps were operated from $18 \mathrm{~h} 30$ to $06 \mathrm{~h} 30$, and checked simultaneously every hour by JEH and two trained assistants. Arctiidae, Saturniidae and Sphingidae moths were collected manually from both sides of the sheets and the immediately surrounding areas, using a killing bottle charged with ethyl acetate. The 15 sites were sampled twice each, with one repeat in each of two rotations (mean interval between consecutive samples at the same site $\pm \mathrm{SD}=27.6 \pm 9.9 \mathrm{~d}, \mathrm{~N}=15$ sites), resulting in a total sampling effort of 30 trap-nights (two trap-nights or 24 trap-hours per site). The sampling order of sites within each rotation was controlled to account for the fraction of the moon illuminated (http://aa. usno.navy.mil/data/docs/MoonPhase.html) and to avoid any systematic bias from the well-documented influences 
of weather on light-trap captures (Fry \& Waring 2001, Spalding \& Parsons 2004, Yela \& Holyoak 1997). Catches were also restricted to periods without strong moonlight by avoiding nine nights around the full moon (Yela \& Holyoak 1997), and weather conditions were recorded every hour during sampling. Bulbs were protected from above but any broken by rain were immediately replaced.

Collected moths were oven-dried and identified at the Entomology Department of the Instituto Nacional de Pesquisas da Amazônia (INPA) in Manaus using the INPA reference collection and available guides (d'Abrera 1995, 1998; Kitching \& Cadiou 2000, Lemaire 1988, PiñasRubio \& Pesántez 2000, Piñas-Rubio et al. 2000, http:// www.inra.fr/Internet/Produits/PAPILLON/arct_guy/ar ct_guy.htm). Morphospecies were identified by INPA staff using anatomical features and wing patterns, with care taken to minimize over-splitting as a result of sexual dimorphism or natural variation. Specimens of all species and morphospecies were subsequently deposited at INPA.

\section{Vegetation sampling}

Trees and woody lianas were sampled along the same transect lines in each of the 15 sites. We measured all standing trees $\geq 10 \mathrm{~cm}$ in diameter at breast height (dbh) and lianas $\geq 5 \mathrm{~cm}$ in a $10 \times 1000-\mathrm{m}$ plot established at each of the 10 primary and secondary forest sites. Basal area in plantations was estimated from 2310 -m radial plots per site $\left(7226 \mathrm{~m}^{2}\right)$ and converted to basal area per hectare. Density of saplings (taller than $1 \mathrm{~m}$ and $<10 \mathrm{~cm}$ $\mathrm{dbh})$, and lianas $(<5 \mathrm{~cm} \mathrm{dbh})$ were determined by recording all stems within three $2.5 \times 2.5-\mathrm{m}\left(6.25 \mathrm{~m}^{2}\right)$ subplots placed at 23 locations every $50 \mathrm{~m}$ along each transect (total of 69 subplots per site).

Canopy cover and understorey density were measured at each light trap location following the methodology of Barlow et al. (2002). A reading with a spherical densiometer (Lemmon 1957) was taken in each of the four compass directions and averaged before converting to a percentage canopy cover. Similarly, a $2.5-\mathrm{m}$ graded pole was used to estimate understorey density. In each of the four compass directions, the number of $10-\mathrm{cm}$ sections visible from a distance of $15 \mathrm{~m}$, were recorded and converted to a percentage density.

\section{Land-cover analysis}

A geographic information system (GIS) was employed to measure the relative extent of different forest types in the immediate surroundings of any given site. A landcover classification was developed from a combination of land-use data provided by Jari Celulose S.A and a semi-supervised classification of a 2003 Landsat 7 (30-m pixel) image. Buffer rings were created around the central point of each moth sampling site before performing an intersect overlay with layers containing data on landcover types. Three kilometres was selected as the buffer radius as this exceeds the expected attraction of lighttraps (Baker \& Sadovy 1978), yet falls within the flight capacity range of large-bodied moths (I. Kitching pers. comm.).

\section{Statistical analyses}

Total moth abundances per trap-night were compared between each forest type using one-way ANOVAs with Tukey's post-hoc test. To highlight the variable effectiveness of light-traps in different vegetation types (e.g. the greater light penetration distance in Eucalyptus plantations compared with the dense undergrowth of secondary forests) we repeated these analyses with abundance per trap-night divided by the area effectively surveyed by each light-trap (calculated from our trapradius measurements).

There is currently no general consensus on an optimal method to deal with the difficult problem of variable attraction radii for light-traps in different forest types (Beck \& Linsenmair 2006). Human perception of trap-attraction differs from moths so ideally UV light penetration would be measured, Mark-Release-Recapture experiments would be performed and standardization would also account for the three-dimensional catchment of each trap. However, we feel that the simple standardization we performed indicates the possible impacts of variable vegetation density and emphasizes that crude abundances should be interpreted with caution.

For assessing species richness and alpha diversity, the raw catch data were pooled from the three individual traps from both nights at a given site, as sample sizes were insufficient to compare the relative attractions of lamps with different spectral emissions. The observed number of species per site gives a poor and often misleading indication of total richness because of the virtual impossibility of obtaining a complete inventory of speciesrich tropical invertebrate communities (Price et al. 1995). More suitable estimates are given by the extrapolation of species accumulation curves or the shape of the speciesabundance distribution (Magurran 2004). Rarefaction and non-parametric estimators also provide powerful approaches to estimate species richness (Gotelli \& Colwell 2001). Sample-based rarefaction curves were therefore produced for the three forest types, and an average of three abundance based estimators (Chao1, Jack1 and ACE) was calculated for each site using EstimateS 7.5 (R. K. Colwell, http://purl.oclc.org/estimates). 
Species-abundance relationships were examined using standardized Whittaker plots. To assess alpha diversity we calculated Fisher's alpha of the logarithmic series distribution (Fisher et al. 1943), which has been widely used in tropical moth diversity studies and is relatively independent of sample size (Magurran 2004).

Patterns of community structure and composition among different sites and between forest types were visualized using non-metric multidimensional scaling (NMDS) of a similarity matrix based on the BrayCurtis index (standardized and square root-transformed). The analyses were performed on both abundance (quantitative) and presence/absence (qualitative) data. Abundance data reveal patterns based primarily on the common species (i.e. community structure), whereas presence/absence data give more weight to the distribution of rare species (i.e. community composition). Differences between forest types were assessed using an analysis of similarities (ANOSIM), and the identity of species contributing most to any differences was determined using an analysis of percentage similarities (SIMPER) (Clarke \& Warwick 2001).

The influence of the forest type surrounding study sites was investigated using a Spearman's correlation of the amount of primary forest within a 3-km buffer against rarefied species richness. The effects of surrounding primary forest plus other environmental parameters (lunar phase, weather conditions and forest structure), as well as the geographic distance between sites on community structure were assessed using the BIOENV and RELATE (analogous to a Mantel test) functions respectively. Community analyses were conducted using Primer 5 (PRIMER-E Ltd., Plymouth, UK).

\section{RESULTS}

\section{Moth abundance and species richness}

A total of 1848 moth individuals were collected during the 30 trap-nights at 15 sites. These comprised 974 Arctiidae individuals of 231 species, 772 Saturniidae individuals of 65 species, and 102 Sphingidae individuals of 39 species. Of these, 452 Arctiidae and 11 Saturniidae were identified to 160 and six morphospecies respectively. Sample sizes in this short-term study were therefore relatively small, particularly for the Sphingidae. For a full species list see Appendix 1 (supplementary material).

Total abundance of the three moth families ranged from 42 to 264 individuals per site. The abundance patterns for each family closely resemble the pattern for the three families combined where mean abundance per trap-night differed significantly among forest types (Figure 2; ANOVA: $F_{2,87}=5.8, \mathrm{P}=0.004$ ), with fewer moths captured in secondary forests than in either primary forests or Eucalyptus plantations. With the overall abundance of trap-night samples standardized in relation to the light-trap areas there were still significant differences among forest types (Figure 2; $F_{2,87}$ $=8.6, \mathrm{P}<0.001$ ) but this standardized catch was lower in Eucalyptus plantations than in either primary and secondary forests. Again, this pattern was similar for each family separately, although differences among forest types were not as clear for the Sphingidae.

Rarefaction curves for all three families combined showed slightly higher levels of species richness in secondary forest and Eucalyptus plantations than in primary forest, although the differences between all three forest types were only marginally significant (Figure 3). This pattern was driven mainly by the pattern within Arctiidae, while Saturniidae showed a lower species richness in Eucalyptus plantations than primary and secondary forest. There were no differences between forest types for Sphingidae, where the sample sizes were smallest.

Comparing observed species richness with the average richness estimate shows that a complete inventory was not achieved for any family in any of the three forest types (Table 2). Values for Fisher's alpha did not differ significantly between forest types for the three families combined or within each family (Table 2). No difference between forest types was evident in the proportions of local singletons captured at a site for the three families combined $\left(F_{2,12}=2.2, \mathrm{P}=0.152\right)$.

\section{Community structure and composition}

Levels of dominance were similar in the three forest types with long tails of rare species in each case. When examining only the 25 most abundant species in each forest type (Figure 4), secondary forests appear to exhibit the lowest levels of dominance, with most of the dominance in primary forest accounted for by just one species, Evius albicoxae (108 individuals from 677 primary forest captures). However, few of the 25 most abundant species in primary forest were also the most abundant species in secondary forests or Eucalyptus plantations, indicating a high level of community turnover.

This is supported by the two-dimensional NMDS ordination plot based on abundance data for the three families combined, which shows a distinct grouping of sites into the three forest types (Figure 5; Global ANOSIM: $R=0.75, \mathrm{P}=0.001)$ and significant differences between each pair of forest types (Pairwise ANOSIM between primary (PF), secondary forest (SF) and Eucalyptus plantation (EUC): PF-SF (i.e. between primary and secondary forests): $R=0.64, \mathrm{P}=0.008$; PF-EUC: $R=0.96$, $\mathrm{P}=0.008$; SF-EUC: $R=0.58, \mathrm{P}=0.008)$. An NMDS 

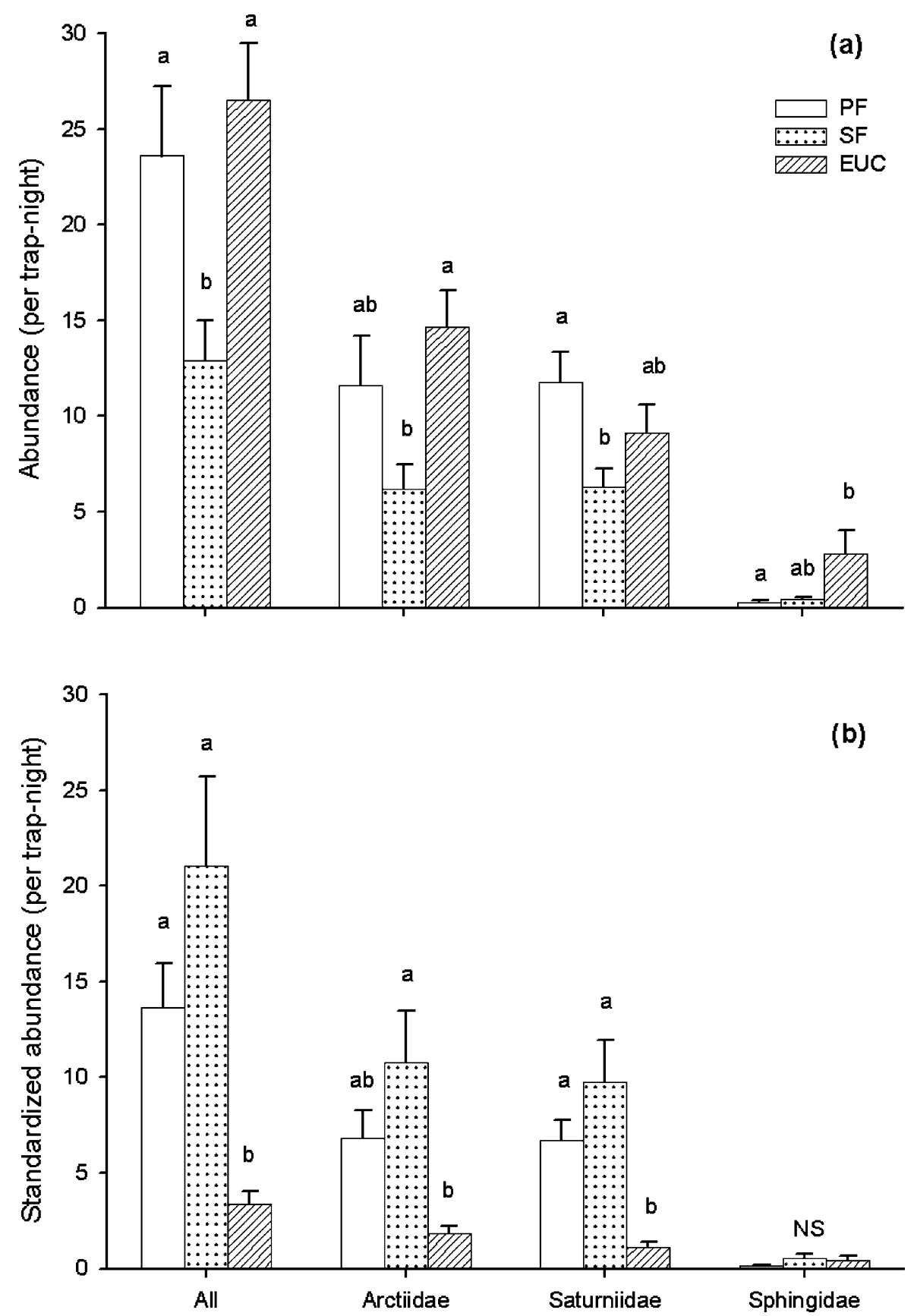

Figure 2. Abundance (mean \pm SE) of Arctiidae, Saturniidae, Sphingidae and all families combined, captured in primary (PF) and secondary forests (SF), and Eucalyptus plantations (EUC) per trap-night (a) and standardized by trap-area surveyed per trap-night (b). Letters above bars denote Tukey's HSD subsets.

plot based on presence/absence data (i.e. examining community composition) shows the same grouping into forest types (Global ANOSIM: $R=0.64, \mathrm{P}=0.001$; Pairwise ANOSIM: PF-SF: $R=0.60, \mathrm{P}=0.008$; PFEUC: $R=0.84, \mathrm{P}=0.008$; SF-EUC: $R=0.44, \mathrm{P}=0.008$ ). Examining community structure for the three families separately (Figure 5) shows significant differences between all forest types for both Arctiidae (PF-SF: $R=0.32, \mathrm{P}=0.032$; PF-EUC: $R=0.82, \mathrm{P}=0.008$; SF-
EUC: $R=0.51, P=0.008$ ) and Saturniidae (PF-SF: $R=0.51, \mathrm{P}=0.016$; PF-EUC: $R=0.88, \mathrm{P}=0.008$; SFEUC: $R=0.51, P=0.016$ ), but for Sphingidae only primary forest and Eucalyptus plantation held distinct communities (PF-SF: $R=0.10, \quad \mathrm{P}=0.206$; PF-EUC: $R=0.54, \mathrm{P}=0.008$; SF-EUC: $R=0.13, \mathrm{P}=0.206$ ).

The sampling session had a significant influence on the overall pattern of community structure (ANOSIM: $R=$ $0.24, \mathrm{P}=0.004)$ but significant differences among forest 

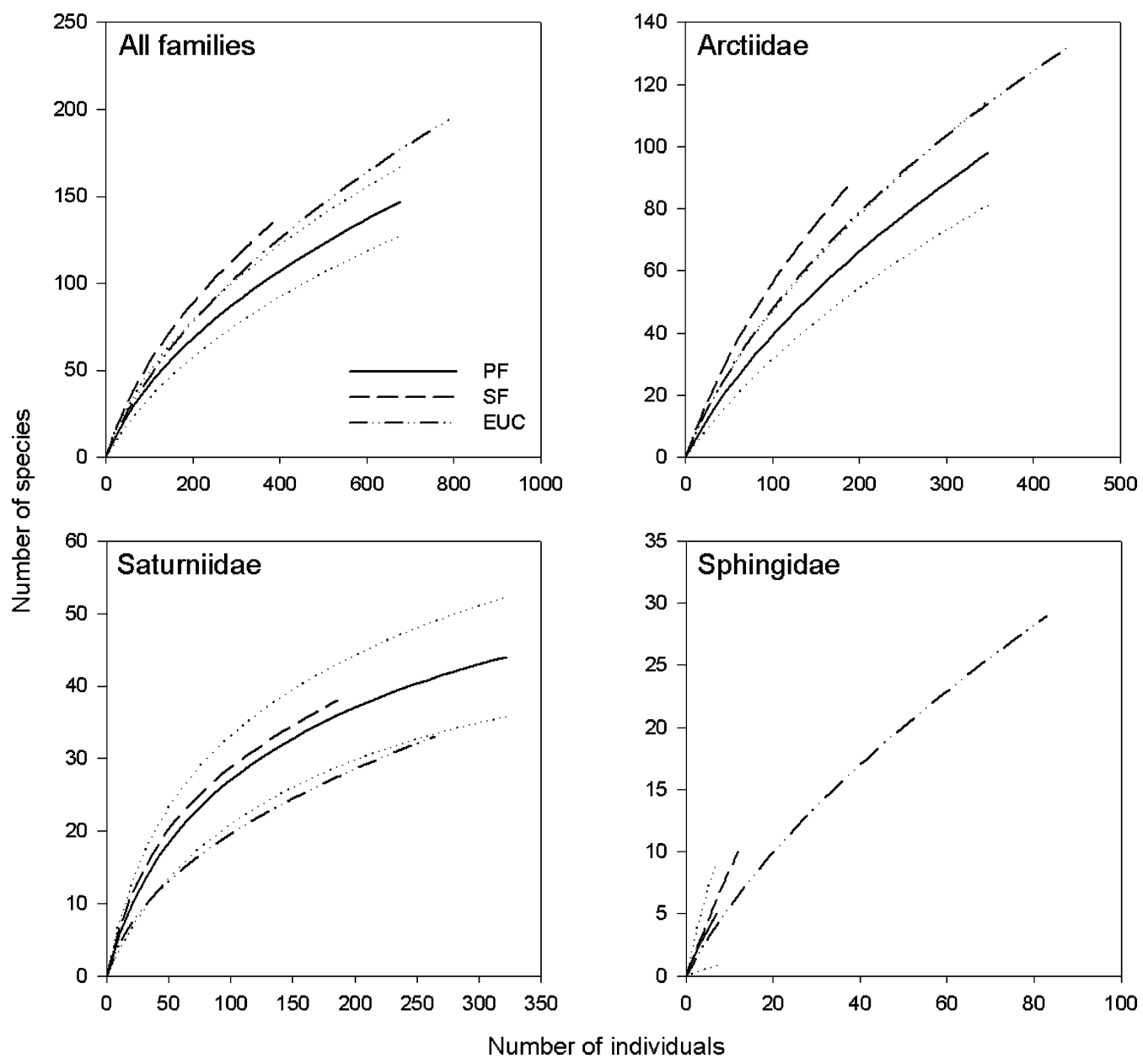

Figure 3. Sample-based rarefaction curves for Arctiidae, Saturniidae, Sphingidae and all families combined, sampled in primary (PF) and secondary forests (SF), and Eucalyptus plantations (EUC). X-axis rescaled to show mean number of individuals per sample. Dotted lines show $95 \%$ confidence intervals.

types remained consistent when analysing the data for each session independently. This was also confirmed by a two-way crossed analysis of similarities that shows a difference in community structure between forest types whilst averaging across sampling rounds (ANOSIM: $R=$ 0.49, $\mathrm{P}=0.001$ ).

Beta diversity (Bray-Curtis dissimilarity) values were highest between primary forest and Eucalyptus plantations (84\%) but all forest types supported largely unique communities (Figure 6), with five species contributing $9-11 \%$ of the total dissimilarity in each pairwise forest comparison (Table 3). Primary forest sites were distinct largely due to (1) an abundance of species rarely found in disturbed forest types (Evius albicoxae and Adeloneivia subangulata) and (2) lower relative densities or absence of species common in secondary forests (e.g. Dirphia tarquina and Periga cynira) and Eucalyptus plantations (e.g. Automeris liberia and Idalus admirabilis) (Table 2).

\section{Responses to forest type and landscape structure}

The BIO-ENV analysis identified canopy cover as the best single predictor of moth community structure when examining all forest types combined (Table 4). Basal area of lianas and basal area of live trees were the best predictors in primary and secondary forests respectively, whereas the moth community structure in plantation sites was strongly correlated to the attraction radius of the light-traps, which was significantly negatively correlated with both understorey density $(r=-0.862$, $\mathrm{P}<0.001)$ and canopy cover $(r=-0.921, \mathrm{P}<0.001)$. The amount of primary forest within $3 \mathrm{~km}$ was not identified as a strong predictor in the BIO-ENV analysis and geographic distance between sites was also not related to patterns of community dissimilarity (RELATE: Rho = $0.09, \mathrm{P}=0.738$ ). There was no difference in the lunar phase across forest types (mean fraction of the moon visible per night; $\left.F_{2,30}=0.564, \mathrm{P}=0.583\right)$. 
Table 2. Detailed results of the sampling for Arctiidae, Saturniidae and Sphingidae at the 15 light-trapping sites within primary (PF) and secondary forests (SF), and Eucalyptus plantations (EUC). Site names: $\mathrm{B}=$ Bituba, $\mathrm{C}=$ Castanhal, $\mathrm{E}=$ Estaçao, $\mathrm{P}=$ Pacanari, $\mathrm{Q}=\mathrm{Quaruba}$. $\mathrm{N}=$ number of individuals captured, Sobs $=$ observed species richness, Richness estimate $=$ average of three abundance-based richness estimators (Chao 1 , Jack 1 and ACE). Significance was calculated with one-way ANOVAs, F = F-ratio.

\begin{tabular}{|c|c|c|c|c|c|c|c|c|c|c|c|c|c|}
\hline \multirow[b]{2}{*}{$\begin{array}{c}\text { Habitat } \\
\text { type }\end{array}$} & \multirow[b]{2}{*}{ Site name } & \multicolumn{4}{|c|}{ Arctiidae } & \multicolumn{4}{|c|}{ Saturniidae } & \multicolumn{4}{|c|}{ Sphingidae } \\
\hline & & $\mathrm{N}$ & Sobs & $\begin{array}{l}\text { Richness } \\
\text { estimate }\end{array}$ & Fisher's $\alpha$ & $\mathrm{N}$ & Sobs & $\begin{array}{l}\text { Richness } \\
\text { estimate }\end{array}$ & Fisher's $\alpha$ & $\mathrm{N}$ & Sobs & $\begin{array}{l}\text { Richness } \\
\text { estimate }\end{array}$ & Fisher's $\alpha$ \\
\hline$\overline{\mathrm{PF}}$ & B & 56 & 19 & 47.9 & 10.1 & 68 & 14 & 17.1 & 5.4 & 1 & 1 & 1.3 & - \\
\hline $\mathrm{PF}$ & C & 37 & 25 & 72.7 & 33.8 & 40 & 20 & 37.1 & 15.9 & 3 & 2 & 3.1 & 2.6 \\
\hline $\mathrm{PF}$ & $\mathrm{E}$ & 78 & 48 & 210.2 & 53.1 & 44 & 18 & 26.1 & 11.4 & 2 & 2 & 3.2 & - \\
\hline $\mathrm{PF}$ & $\mathrm{P}$ & 149 & 37 & 109.2 & 15.8 & 115 & 27 & 36.3 & 11.1 & 0 & 0 & 0.0 & - \\
\hline $\mathrm{PF}$ & Q & 28 & 13 & 44.4 & 9.4 & 54 & 17 & 28.4 & 8.5 & 1 & 1 & 1.3 & - \\
\hline $\mathrm{PF}$ & Mean & 69.6 & 28.4 & 96.9 & 24.5 & 64.2 & 19.2 & 29.0 & 10.5 & 1.4 & 1.2 & 1.8 & 2.6 \\
\hline SF & 55 & 58 & 36 & 196.7 & 40.5 & 48 & 17 & 24.3 & 9.4 & 2 & 2 & 3.2 & - \\
\hline SF & 56 & 43 & 32 & 85.6 & 56.7 & 49 & 19 & 54.8 & 11.4 & 1 & 1 & 1.3 & - \\
\hline SF & 75 & 35 & 18 & 52.8 & 14.9 & 45 & 21 & 36.9 & 15.3 & 5 & 5 & 13.1 & - \\
\hline SF & 86 & 17 & 15 & 49.5 & 61.2 & 23 & 10 & 12.1 & 6.7 & 2 & 1 & 1.3 & 0.8 \\
\hline SF & 91 & 33 & 22 & 37.8 & 28.8 & 21 & 11 & 16.7 & 9.3 & 2 & 2 & 3.2 & - \\
\hline SF & Mean & 37.2 & 24.6 & 84.5 & 40.4 & 37.2 & 15.6 & 28.9 & 10.4 & 2.4 & 2.2 & 4.4 & 0.8 \\
\hline EUC & 10 & 70 & 22 & 43.4 & 11.0 & 27 & 4 & 4.5 & 1.3 & 3 & 1 & 1.0 & 0.5 \\
\hline EUC & 14 & 80 & 33 & 62.7 & 21.0 & 29 & 8 & 13.9 & 3.7 & 9 & 5 & 7.9 & 4.6 \\
\hline EUC & 52 & 54 & 24 & 55.9 & 16.6 & 86 & 9 & 14.5 & 2.5 & 1 & 1 & 1.3 & - \\
\hline EUC & 95 & 118 & 67 & 149.0 & 64.3 & 48 & 22 & 52.5 & 15.7 & 56 & 24 & 46.2 & 15.9 \\
\hline EUC & 127 & 118 & 52 & 232.7 & 35.5 & 74 & 19 & 29.5 & 8.3 & 14 & 8 & 13.5 & 7.8 \\
\hline EUC & Mean & 88 & 39.6 & 108.7 & 29.7 & 52.8 & 12.4 & 23.0 & 6.3 & 16.6 & 7.8 & 14.0 & 7.2 \\
\hline $\mathrm{F}$ & & 2.9 & 1.4 & 0.1 & 0.8 & 1.5 & 1.6 & 0.3 & 1.4 & 2.1 & 2.0 & 1.6 & - \\
\hline
\end{tabular}

The main difference in land-cover within $3 \mathrm{~km}$ of sample sites in secondary forest and Eucalyptus plantations was the proportion of primary forest, varying from $2.5 \%$ to $61.2 \%$. However, there were no significant relationships between the amount of primary forest and moth alpha diversity within either secondary forests or Eucalyptus plantations. Nevertheless, the areas surrounding the two Eucalyptus sites containing the highest levels of alpha diversity (Areas 95 and 127) had the highest proportion of primary forest (Table 1).

Table 3. Breakdown of average community dissimilarity (diss.) between primary (PF) and secondary forests (SF), and Eucalyptus plantations (EUC) into percentage contributions from each species. The five species with the greatest contribution are shown for each habitat-pair comparison in order of decreasing contribution. Arc $=$ Arctiidae, Sat $=$ Saturniidae, Diss. $/ \mathrm{SD}=$ the ratio of dissimilarity to the standard deviation of dissimilarity: higher values indicate a more consistent contribution to differences between communities.

\begin{tabular}{lcccccc}
\hline Species & Family & Average abundance & Average diss. & Diss./ SD & $\begin{array}{c}\text { Contribution } \\
\text { to diss. (\%) }\end{array}$ \\
\hline PF-EUC Average diss. = 84.2 & & PF & EUC & & & \\
Automeris liberia & Sat & 0.0 & 12.4 & 2.3 & 1.8 & 2.8 \\
Idalus admirabilis & Arc & 0.2 & 9.0 & 1.9 & 2.7 & 2.3 \\
Adeloneivaia subangulata & Sat & 7.4 & 0.0 & 1.9 & 1.6 & 2.3 \\
Evius albicoxae & Arc & 21.6 & 3.6 & 1.7 & 1.4 & 2.1 \\
Periphoba arcaei & Sat & 0.6 & 7.6 & 1.6 & 1.3 & 1.9 \\
PF-SF Average diss. $=79.2$ & & PF & SF & & & \\
Evius albicoxae & Arc & 21.6 & 1.8 & 1.7 & 1.4 & 2.1 \\
Adeloneivaia subangulata & Sat & 7.2 & 2.4 & 1.6 & 1.4 & 2.0 \\
Dirphia tarquinia & Sat & 0.2 & 3.6 & 1.4 & 1.6 & 1.8 \\
Periga cynira & Sat & 1.2 & 3.8 & 1.3 & 1.5 & 1.7 \\
Automeris midea & Sat & 6.8 & 0.2 & 1.3 & 1.4 & 1.6 \\
SF-EUC Average diss. $=79.0$ & & SF & EUC & & & \\
Periga cynira & Sat & 3.8 & 0.6 & 1.8 & 1.8 & 2.3 \\
Idalus admirabilis & Arc & 3.0 & 9.0 & 1.7 & 2.5 & 2.2 \\
Automeris liberia & Sat & 2.2 & 12.4 & 1.6 & 1.2 & 2.0 \\
Eacles penelope & Sat & 1.2 & 14.8 & 1.6 & 1.2 & 2.0 \\
Dirphia tarquinia & Sat & 3.6 & 0.0 & 1.5 & 1.6 & 1.9 \\
\hline
\end{tabular}



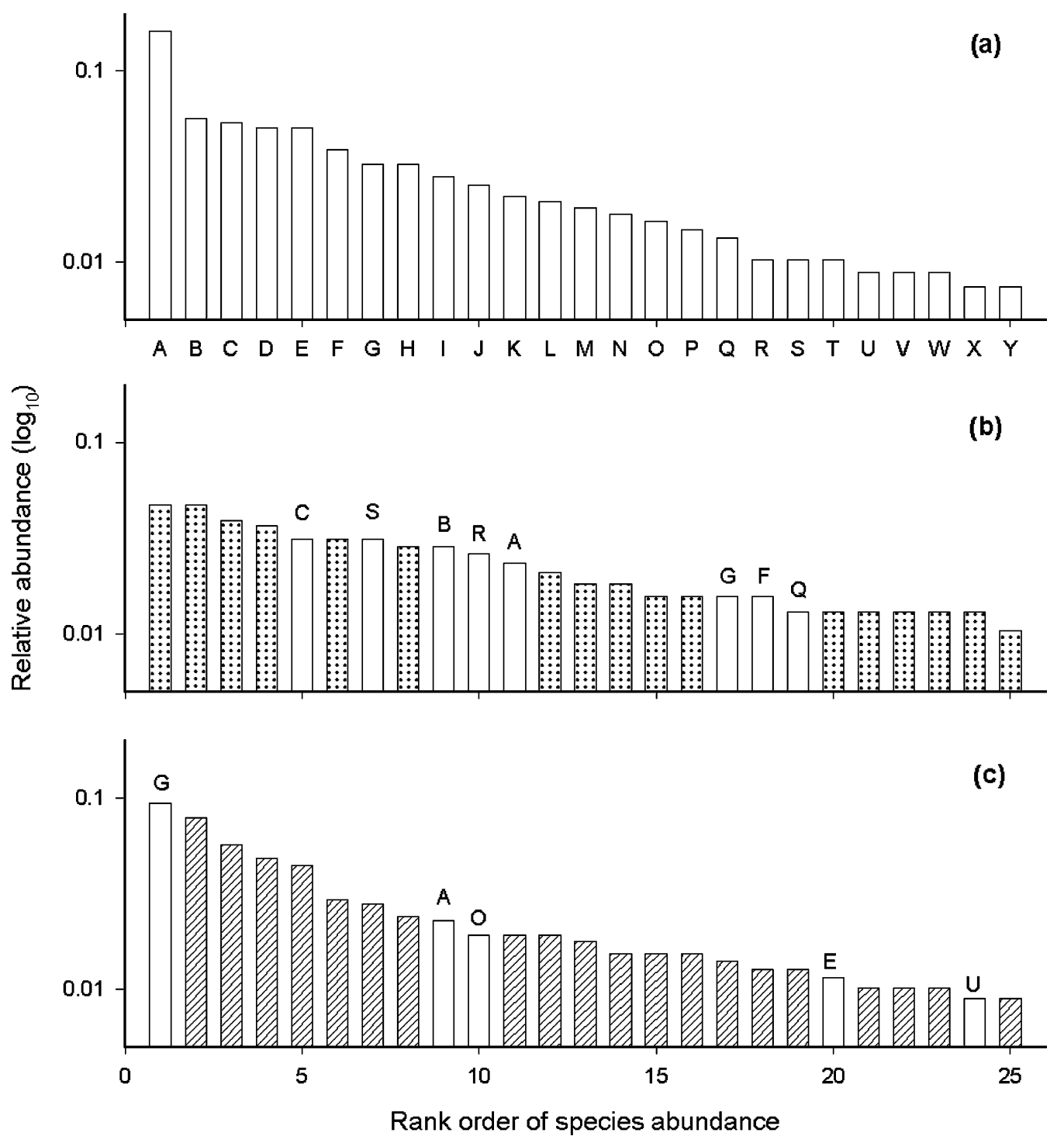

Figure 4. Whittaker plots for moth species sampled in primary forest (a), secondary forest (b) and Eucalyptus plantation (c). Steeper plots indicate higher dominance. Open bars in (b) and (c) represent species shared with primary forest, which are labelled with letter codes corresponding to those in (a) and the species list in Appendix 1.

Table 4. Results of BIO-ENV analysis showing the relationships of moth community structure and weather, habitat and landscape variables in primary (PF) and secondary forests (SF), Eucalyptus plantations (EUC), and all habitats combined. $\mathrm{CC}=$ canopy cover, $\mathrm{UD}=$ understorey density, $\mathrm{LR}=$ light-trap radius, $\mathrm{BAL}=$ basal area of lianas $\geq 5 \mathrm{~cm} \mathrm{dbh}$, $\mathrm{BAT}=$ basal area of live trees $\geq 10 \mathrm{~cm} \mathrm{dbh}, \mathrm{S}=$ number of saplings $<10 \mathrm{~cm} \mathrm{dbh}, \mathrm{L}=$ number of lianas $<5 \mathrm{~cm} \mathrm{dbh}$, WPCA1 = weather PCA1 score (degree of cloud cover). Other variables analysed: moon phase, proportion of primary forest in a 3-km radius. $\rho \mathrm{W}=$ weighted Spearman's.

\begin{tabular}{lcclclc}
\hline \multirow{2}{*}{ Habitat } & $\begin{array}{c}\text { Best } \\
\text { variable }\end{array}$ & $\rho \mathrm{W}$ & $\begin{array}{l}2^{\text {nd }} \text { best } \\
\text { variable }\end{array}$ & $\rho \mathrm{W}$ & combination & $\rho \mathrm{W}$ \\
\hline PF & BAL & 0.64 & WPCA1 & 0.31 & BAL & 0.64 \\
SF & BAT & 0.71 & CC & 0.42 & CC, BAT & 0.84 \\
EUC & LR & 0.88 & S & 0.67 & CC, S, L & 0.95 \\
All & CC & 0.40 & LR & 0.38 & LR, UD, S, L & 0.56 \\
\hline
\end{tabular}

\section{DISCUSSION}

This is the first study to quantitatively evaluate the diversity patterns and community structure of moth assemblages in a human-dominated landscape in lowland Amazonia. Light-trapping for nocturnal Arctiidae, Saturniidae and Sphingidae in the Jari landscape of Brazilian Amazonia revealed three major patterns: (1) undisturbed primary forests were not distinctly richer or more diverse than secondary forests or Eucalyptus plantations, but each forest type exhibited a distinct community in terms of both structure and composition; (2) species turnover was highest between primary forests and Eucalyptus plantations (highest beta diversity), with secondary forest sites being intermediate; 

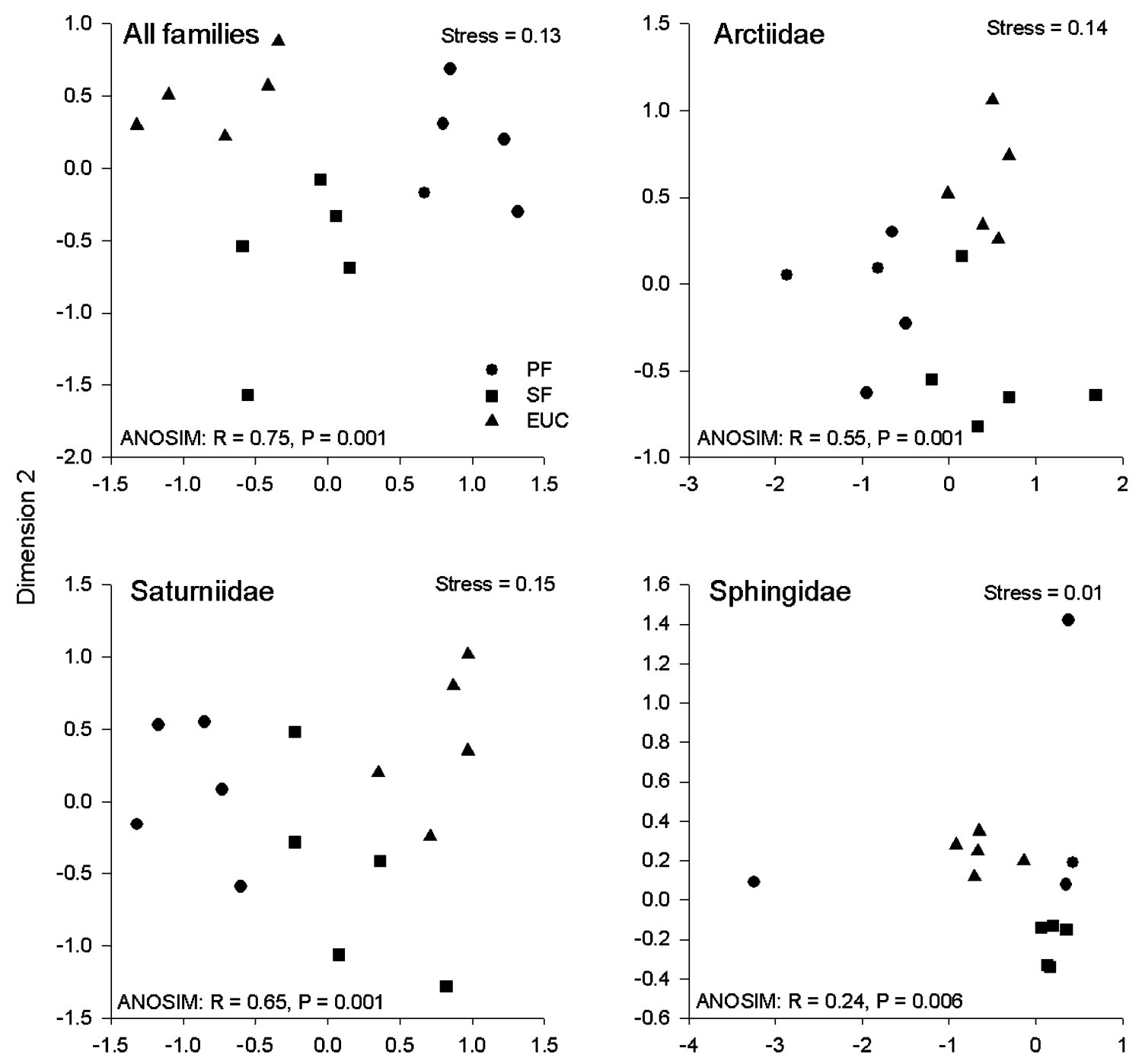

\section{Dimension 1}

Figure 5. Biotic NMDS ordination from species abundances of Arctiidae, Saturniidae, Sphingidae and all families combined, from 15 sites in primary (PF) and secondary forest (SF), and Eucalyptus plantation (EUC).

and (3) the three moth families varied in their response to disturbance in terms of species richness but changes in abundance and community structure were relatively consistent.

\section{Abundance and species richness in primary, secondary and plantation forests}

Total captures of Sphingidae were much lower than those in the other families sampled in this study (Arctiidae and Saturniidae), and they contributed little to any observed community differences between forest types. However, Sphingidae are not expected to be common in the dark primary forest understorey (Schulze et al. 2001) and may not be sensitive to disturbance (Schulze \& Fiedler 2003, cf. Beck et al. 2006). The Arctiidae sampled contain very few from subfamilies Ctenuchinae or Lithosiinae but these are likely to be included in the large number identified only to morphospecies.

The lower overall abundance of all three families in secondary forests could be largely attributed to the dilution effect on the effectiveness of light-traps as a result of denser vegetation (Hilt \& Fiedler 2005, Ricketts et al. 2001). In contrast, light-traps appear especially effective in the relatively open Eucalyptus plantations in attracting moths from a larger surrounding area and, when standardized by trap-area, abundances were actually much lower in Eucalyptus plantations than secondary or primary forests. 

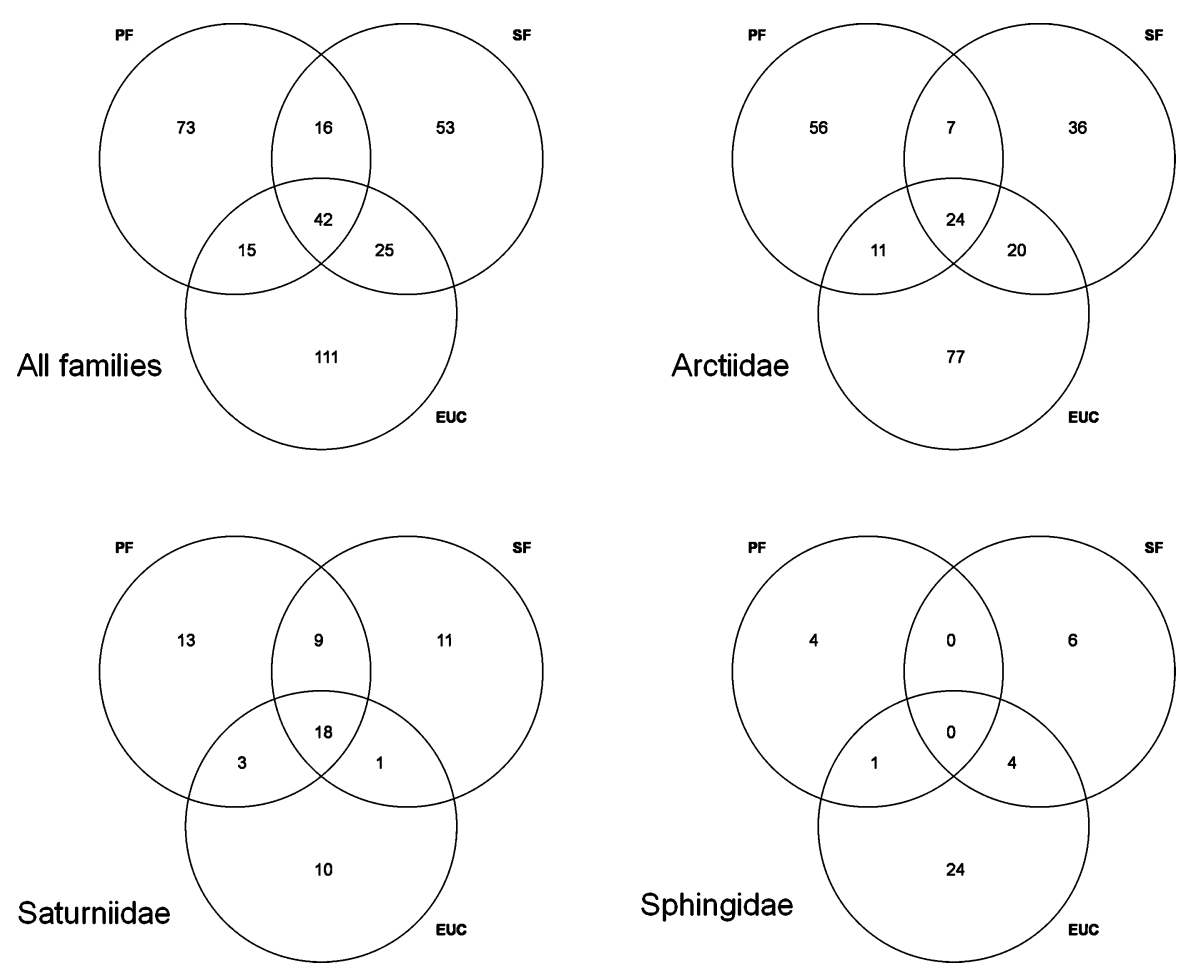

Figure 6. Number of species of Arctiidae, Saturniidae, Sphingidae and all families combined, captured in primary (PF) and secondary forest (SF), and Eucalyptus plantation (EUC).

We are unaware of any other studies that have standardized trap catches by area in terms of the effective visibility of light sources but tentatively suggest that, following experimental testing, this could be a useful approach to compare moth abundances in structurally different forest types. For example, Kitching et al. (2000) detected a higher abundance of Arctiidae in areas of secondary forest regenerated from cleared tropical rain forest in Queensland, Australia. The disparity between this finding and our raw abundances may be in part due to effective light-trap area since our standardized abundances suggest a similar response. Differences in abundance require careful interpretation however, particularly since light-trapping depends strongly on patterns of moth activity and other external factors (Butler et al. 1999, Fiedler \& Schulze 2004), including seasonal differences in moth diversity and abundance (Summerville \& Crist 2003), and variability in collection conditions (Gotelli \& Colwell 2001). Although taxa from different ecological niches can exhibit variable responses to anthropogenic habitat alteration (Stork et al. 2003) the similar abundance patterns we report here suggest a common response by the Arctiidae and Saturniidae.

In contrast, our species richness results do suggest different responses between families. Conversion to plantation forestry has been reported to have potentially irreversible consequences for biodiversity (Holloway et al.
1992, Kanowski et al. 2005), and a reduction in moth species richness in disturbed areas has been observed in a number of tropical forest studies (Beck et al. 2002, Fiedler \& Schulze 2004, Willott 1999). Other studies have reported increases in species richness (Hilt \& Fiedler 2005) and it is important to note that these studies examined moth families with widely differing life-histories (Geometridae, Sphingidae, Arctiidae, Pyralidae).

A 'life-history hypothesis' has been developed to explain the variety of responses between and within families (Beck et al. 2006, Janzen 1984). Income breeders (e.g. Sphingidae: Sphingini and Macroglossini), which feed as adults, are long-lived, strong-flying, and are expected to persist in disturbed environments. Capital breeders (e.g. Saturniidae), which are non-feeding as adults, have a shorter adult life span and are predicted to distribute differentially throughout the landscape, possibly due to differences in mobility and their larval food plant requirements (Beck et al. 2006). Our results show some support for this hypothesis since the Sphingidae show no difference in levels of species richness between forest types, as opposed to lower levels for Saturniidae in Eucalyptus plantations. However, care must be taken with this interpretation, particularly because of the small sample sizes for Sphingidae. The higher levels of species richness for Arctiidae in both secondary forest and Eucalyptus plantations may be explained by the wide range of lifehistory strategies within this family. 
Some support for the life-history hypothesis is given by the similar patterns observed in alpha diversity. No significant differences in Fisher's alpha were detected between forest types for the families analysed either together or separately, but there were lower values for Saturniidae in Eucalyptus plantations and higher values for Arctiidae in secondary forests. Other studies of Sphingidae responses following land-use change have also found no clear differences, even with larger sample sizes (Beck et al. 2006, Chey et al. 1997), but phylogenetic differences between Sphingidae from Asia and America need to be considered here (Beck \& Nässig 2007).

Low sample representation is commonly encountered in tropical insect inventories (Price et al. 1995), and estimates of alpha diversity in primary tropical forest are thus likely to be underestimates, particularly when samples from the forest canopy are not included (Brehm 2007, Dumbrell \& Hill 2005, Willott 1999). Stratification is another important factor in determining diversity patterns (Hilt \& Fiedler 2008) and alpha diversity estimates for Eucalyptus plantations may be positively biased due to higher captures of the often distinct canopy fauna in these families (Brehm 2007, Schulze et al. 2001). The high variability in diversity among individual Eucalyptus sites may potentially be related to variability in the abundance of tourists or vagrants as well, as a result of differences in the effective attraction radii of lighttraps (differences in understorey density) or the amount of primary forest in the surrounding landscape.

\section{Turnover in moth communities following land-use change}

High levels of dominance by a limited number of species are usually expected in more heavily disturbed sites (DeVries et al. 1999, Fiedler \& Schulze 2004). However, we did not find this pattern for the Jari landscape as species-abundance relationships were very similar among forest types and the total number of captures was primarily dominated by few species in primary forest.

Patterns of both community structure and composition differed clearly among forest types, with similar results from NMDS plots based on both abundance and presence/absence data showing that these patterns are driven by differences in the distribution of both rare and common species. Differences between the two sampling sessions at each site may be related to the adult life span of moths since Saturniidae, for example, have an especially short adult phase (Janzen 1984). Combined with the synchronized emergence of adults, this could cause a relatively fast temporal turnover in species active within any one forest type. However, the three forest types had consistently distinct communities in each sampling session and, despite some shared species, each forest type supported a largely unique moth fauna.
These clear patterns representing differential distribution across the landscape were maintained when examining the 'capital breeding' Saturniidae. Only primary forest and Eucalyptus plantations held distinct communities of the mainly 'income breeding' Sphingidae, while the Arctiidae, with a wide range of life-histories, had distinct communities in each forest type. It would be interesting to examine patterns of beta diversity in relation to the 'life-history hypothesis' (Beck et al. 2006) and further variability in responses may also exist within subfamilies or tribes of each of these families (Hilt \& Fiedler 2006) but larger sample sizes would be required.

\section{Moth-environment relationships}

Because forest structure variables were intercorrelated, it is difficult to identify the most important factors determining the observed variation in community structure and composition. Although canopy cover and basal area of trees and lianas were identified as important factors, it is more likely that differences in moth assemblages are primarily determined by the distribution of host-plant resources than differences in physical vegetation structure (Summerville \& Crist 2003). Most moths are herbivorous as larvae and many are noted for their pronounced host-specificity (Holloway et al. 1992). Plant diversity or the presence of particular plant species is therefore critical, both for the emergence of adults and for egg-laying, but investigating the relationship between the moth community structure and plant diversity is hindered by the very limited knowledge of resource use by individual moth species (Brehm et al. 2003).

The strong correlation between light-trap radius and moth species composition in Eucalyptus plantations suggests that trap-effectiveness is a critical factor in plantation sites (Table 4). Forest cover in the immediately surrounding landscape also appears important in determining the local moth community in plantation sites: Area 95 and Area 127 were surrounded by the highest proportion of primary forest within a 3-km radius, contained communities most similar to those in primary forest, and had the highest values of alpha diversity despite the smallest light-trap areas for plantation sites.

\section{CONCLUSION}

Although this study shows that both secondary forests and Eucalyptus plantations are relatively species-rich and diverse compared to primary forest, they each hosted a community structure and composition that was markedly distinct from those in primary forest. For example, half $(51 \%)$ of the species associated with primary forest were entirely absent from the surrounding matrix, as primary 
forest species became replaced by species likely to be geographically widespread disturbance or edge specialists (Dunn 2004, Horner-Devine et al. 2003).

The relatively high levels of species richness and diversity recorded in Eucalyptus plantations and secondary forest may be explained by the landscape heterogeneity, which is known to increase the biodiversity value of plantations (Kanowski et al. 2005, Lindenmayer \& Hobbs 2004), forest fragments (Shahabuddin \& Terborgh 1999), secondary forests and the wider countryside (Horner-Devine et al. 2003). This study provides some support for the life-history hypothesis (Beck et al. 2006) but more detail, including information on variability within families, is required to examine how species traits may interact to determine reactions to disturbance (Koh et al. 2004, Mattila et al. 2006). Finally, comparisons with patterns from other taxa are urgently needed to allow greater understanding of the complex responses of biodiversity to landscape-level habitat changes.

\section{ACKNOWLEDGEMENTS}

We thank the Brazilian Ministerio de Ciencias e Tecnologia $(\mathrm{CNPq})$ and Ministerio do Meio Ambiente (MMA-IBAMA) for permission to conduct this study. We are grateful to Orsa Florestal and Jari Celulose for permission to work on their landholding and logistical support throughout the project. Specimen preparation and identification was performed at INPA with the assistance of Simone Ferreira Trovisco, Francisco Felipe Xavier Filho and Gilcélia Melo Lourido. Additional help was provided by Ian Kitching from the Natural History Museum, London. Philip Judge prepared Figure 1. We thank Jan Beck, Keith Summerville and two anonymous reviewers for constructive comments on earlier versions of the manuscript. The project was funded by the UK Government Darwin Initiative, Conservation International, and a NERC postgraduate studentship to JH. This is publication number 20 of the LandUse Change and Amazonian Biodiversity project (see www.tropicalforestresearch.org).

\section{LITERATURE CITED}

AXMACHER, J. C. \& FIEDLER, K. 2004. Manual versus automatic moth sampling at equal light sources - a comparison of catches from Mt. Kilimanjaro. Journal of the Lepidopterists' Society 58:196-202.

BAKER, R. R. \& SADOVY, Y. 1978. The distance and nature of the light-trap response of moths. Nature 276:818-821.

BARLOW, H. S. \& WOIWOD, I. P. 1989. Moth diversity of a tropical forest in Peninsular Malaysia. Journal of Tropical Ecology 5:3750 .
BARLOW, J., HAUGAASEN, T. \& PERES, C. A. 2002. Effects of ground fires on understorey bird assemblages in Amazonian forests. Biological Conservation 105;157-169.

BARLOW, J., GARDNER, T. A., ARUJO, I. S., BONALDO, B. A., COSTA, J. E., ESPOSITO, M. C., FERREIRA, L. V., HAWES, J. E., HERNANDEZ, M. I. M., LEITE, R. N., LO-MAN-HUNG, N. F., MALCOLM, J. R., MARTINS, M. B., MESTRE, L. A. M., NUNES-GUTJAHR, A. L., OVERAL, W. L., PARRY, L., PETERS, S. L., RIBEIRO-JUNIOR, M. A., DA SILVA MOTTA, C., DA SILVA, M. N. F. \& PERES, C. A. 2007. Quantifying the biodiversity value of tropical primary, secondary and plantation forests. Proceedings of the National Academy of Sciences USA 104:18555-18560.

BECK, J. \& LINSENMAIR, K. E. 2006. Feasibility of light-trapping in community research on moths: attraction radius of light, completeness of samples, nightly flight times and seasonality of Southeast-Asian hawkmoths (Lepidoptera: Sphingidae). Journal of Research on the Lepidoptera 39:18-37.

BECK, J. \& NÄSSIG, W. A. 2007. Diversity and abundance patterns, and revised checklist, of saturniid moths from Borneo (Lepidoptera: Saturniidae). Nachrichten des Entomologischen Vereins Apollo 28:155164.

BECK, J., SCHULZE, C. H., LINSENMAIR, K. E. \& FIEDLER, K. 2002. From forest to farmland: diversity of geometrid moths along two habitat gradients on Borneo. Journal of Tropical Ecology 18:3351.

BECK, J., KITCHING, I. J. \& LINSENMAIR, K. E. 2006. Effects of habitat disturbance can be subtle yet significant: biodiversity of hawkmoth-assemblages (Lepidoptera: Sphingidae) in SoutheastAsia. Biodiversity and Conservation 15:465-486.

BREHM, G. 2007. Contrasting patterns of vertical stratification in two moth families in a Costa Rican lowland rain forest. Basic and Applied Ecology 8:44-54.

BREHM, G., SUSSENBACH, D. \& FIEDLER, K. 2003. Unique elevational diversity patterns of geometrid moths in an Andean montane rainforest. Ecography 26:456-466.

BROOK, B. W., BRADSHAW, C. J. A., KOH, L. P. \& SODHI, N. S. 2006. Momentum drives the crash: mass extinction in the tropics. Biotropica 38:302-305.

BUTLER, L., KONDO, C., BARROWS, E. M. \& TOWNSEND, E. C. 1999. Effects of weather conditions and trap types on sampling for richness and abundance of forest macrolepidoptera. Environmental Entomology 28:795-811.

CHEY, V. K., HOLLOWAY, J. D. \& SPEIGHT, M. R. 1997. Diversity of moths in forest plantations and natural forests in Sabah. Bulletin of Entomological Research 87:371-385.

CLARKE, K. R. \& WARWICK, R. M. 2001. Change in marine communities: an approach to statistical analysis and interpretation. (Second edition). Primer-E Ltd, Plymouth. 144 pp.

COUTINHO, S. D. C. \& PIRES, M. J. P. 1996. Jari: um banco genético para o futuro. Imago Editora Ltda., Rio de Janeiro. 242 pp.

D'ABRERA, B. 1995. Saturniidae Mundi: saturniid moths of the world. Volume 1. Automeris Press, Keltern. 177 pp.

D'ABRERA, B. 1998. Saturniidae Mundi: saturniid moths of the world. Volume 3. Automeris Press, Keltern. 171 pp.

DAILY, G. C. 2001. Ecological forecasts. Nature 411:245. 
DEVRIES, P. J., WALLA, T. R. \& GREENEY, H. F. 1999. Species diversity in spatial and temporal dimensions of fruit-feeding butterflies from two Ecuadorian rainforests. Biological Journal of the Linnean Society 68:333-353.

DUMBRELL, A. J. \& HILL, J. K. 2005. Impacts of selective logging on canopy and ground assemblages of tropical forest butterflies: implications for sampling. Biological Conservation 125:123-131.

DUNN, R. R. 2004. Managing the tropical landscape: a comparison of the effects of logging and forest conversion to agriculture on ants, birds, and lepidoptera. Forest Ecology and Management 191:215-224.

EVANS, J. \& TURNBULL, J. 2004. Plantation forestry in the tropics. (Third edition). Oxford University Press, Oxford. 488 pp.

FIEDLER, K. \& SCHULZE, C. H. 2004. Forest modification affects diversity (but not dynamics) of speciose tropical pyraloid moth communities. Biotropica 36:615-627.

FISHER, R. A., CORBET, A. S. \& WILLIAMS, C. B. 1943. The relation between the number of species and the number of individuals in a random sample of an animal population. Journal of Animal Ecology 12:42-58.

FRY, R. \& WARING, P. 2001. A guide to moth traps and their use. (Second edition). The Amateur Entomologists' Society, London. 68 pp.

GARDNER, T. A., BARLOW, J., PARRY, L. W. \& PERES, C. A. 2007. Predicting the uncertain future of tropical forest species in a data vacuum. Biotropica 39:25-30.

GARDNER, T. A., BARLOW, J., ARUJO, I. S., AVILA-PIRES, T. C. S., BONALDO, B. A., COSTA, J. E., ESPOSITO, M. C., FERREIRA, L. V., HAWES, J. E., HERNANDEZ, M. I. M., HOOGMOED, M., LEITE, R. N., LO-MAN-HUNG, N. F., MALCOLM, J. R., MARTINS, M. B., MESTRE, L. A. M., MIRANDA-SANTOS, R., NUNES-GUTJAHR, A. L., OVERAL, W. L., PARRY, L., PETERS, S. L., RIBEIRO-JUNIOR, M. A., DA SILVA, M. N. F., DA SILVA MOTTA, C. \& PERES, C. A. 2008. The costeffectiveness of biodiversity surveys in tropical forests. Ecology Letters 11:139-150.

GOTELLI, N. J. \& COLWELL, R. K. 2001. Quantifying biodiversity: procedures and pitfalls in the measurement and comparison of species richness. Ecology Letters 4:379-391.

HARTLEY, M. J. 2002. Rationale and methods for conserving biodiversity in plantation forests. Forest Ecology and Management 155:81-95.

HILT, N. \& FIEDLER, K. 2005. Diversity and composition of Arctiidae moth ensembles along a successional gradient in the Ecuadorian Andes. Diversity and Distributions 11:387-398.

HILT, N. \& FIEDLER, K. 2006 Arctiid moth ensembles along a successional gradient in the Ecuadorian montane rain forest zone: how different are subfamilies and tribes? Journal of Biogeography 33:108-120.

HILT, N.\& FIEDLER, K. 2008. Successional stages of faunal regeneration - a case study on megadiverse moths. Pp. 443-449 in Beck, E., Bendix, J., Kottke, I., Makeschin, F. \& Mosandl, R. (eds.). Gradients in a tropical mountain ecosystem of Ecuador. Ecological Studies Volume 198. Springer Verlag, Berlin.

HILT, N., BREHM, G. \& FIEDLER, K. 2006 Diversity and ensemble composition of geometrid moths along a successional gradient in the Ecuadorian Andes. Journal of Tropical Ecology 22:155166.
HOLLOWAY, J. D., KIRKSPRIGgS, A. H. \& CHEY, V. K. 1992. The response of some rain-forest insect groups to logging and conversion to plantation. Philosophical Transactions of the Royal Society of London Series B-Biological Sciences 335:425-436.

HORNER-DEVINE, M. C., DAILY, G. C., EHRLICH, P. R. \& BOGGS, C. L. 2003. Countryside biogeography of tropical butterflies. Conservation Biology 17:168-177.

INTACHAT, J. \& WOIWOD, I. P. 1999. Trap design for monitoring moth biodiversity in tropical rainforests. Bulletin of Entomological Research 89:153-163.

JANZEN, D. H. 1984. Two ways to be a tropical big moth: Santa Rosa saturniids and sphingids. Oxford Surveys in Evolutionary Biology 1:85140.

JANZEN, D. H. 1987. Insect diversity of a Costa Rican dry forest - why keep it, and how. Biological Journal of the Linnean Society 30:343-356.

KANOWSKI, J., CATTERALL, C. P. \& WARDELL-JOHNSON, G. W. 2005. Consequences of broadscale timber plantations for biodiversity in cleared rainforest landscapes of tropical and subtropical Australia. Forest Ecology and Management 208:359-372.

KITCHING, I. J. \& CADIOU, J. M. 2000. Hawkmoths of the world: an annotated and illustrated revisionary checklist (Lepidoptera: Sphingidae). Natural History Museum, London \& Cornell University Press, Ithaca. 226 pp.

KITCHING, R. L., ORR, A. G., THALIB, L., MITCHELL, H., HOPKINS, M. S. \& GRAHAM, A. W. 2000. Moth assemblages as indicators of environmental quality in remnants of upland Australian rain forest. Journal of Applied Ecology 37:284-297.

KOH, L. P., SODHI, N. S. \& BROOK, B. W. 2004. Ecological correlates of extinction proneness in tropical butterflies. Conservation Biology 18:1571-1578.

LEMAIRE, C. 1988. Les Saturniidae Americains - The Saturniidae of America - Los Saturniidae Americanos. Ceratocampinae. Museo Nacional de Costa Rica, San José. 480 pp.

LEMMON, P.E. 1957. A new instrument for measuring forest overstorey density. Journal of Forestry 55:667-668.

LEWINSOHN, T. M., FREITAS, A. V. L. \& PRADO, P. I. 2005. Conservation of terrestrial invertebrates and their habitats in Brazil. Conservation Biology 19:640-645.

LINDENMAYER, D. B. \& HOBBS, R. J. 2004. Fauna conservation in Australian plantation forests - a review. Biological Conservation 119:151-168.

MAGURRAN, A. E. 2004. Measuring biological diversity. Blackwell Science, Oxford. $260 \mathrm{pp}$.

MATTILA, N., KAITALA, V., KOMONEN, A., KOTIAHO, J. S. \& PÄIVINEN, J. 2006. Ecological determinants of distribution decline and risk of extinction in moths. Conservation Biology 20:1161-1168.

MUIRHEAD-THOMSON, R. C. 1991. Trap responses of flying insects. Academic Press, London. 287 pp.

NEEFF, T., LUCAS, R. M., DOS SANTOS, J. R., BRONDIZIO, E. S. \& FREITAS, C. C. 2006. Area and age of secondary forests in Brazilian Amazonia 1978-2002: an empirical estimate. Ecosystems 9:609623.

PIÑAS-RUBIO, F. \& PESÁNTEZ, I. M. 2000. Mariposas del Ecuador/Butterflies \& Moths of Ecuador. Volume 1: Géneros. Pontificia Universidad Católica del Ecuador, Quito. 115 pp. 
PIÑAS RUBIO, F., RAB-GREEN, S., ONORE, G. \& PESÁNTEZ, I. M. 2000. Mariposas del Ecuador/Butterflies \& Moths of Ecuador. Volume 20: Arctiidae (Arctiinae y Pericopinae). Pontificia Universidad Católica del Ecuador, Quito. 215 pp.

PRICE, P. W., DINIZ, I. R., MORAIS, H. C. \& MARQUES, E. S. A. 1995. The abundance of insect herbivore species in the tropics: the high local richness of rare species. Biotropica 27:468-478.

RICKETTS, T. H., DAILY, G. C., EHRLICH, P. R. \& FAY, J. P. 2001. Countryside biogeography of moths in a fragmented landscape: biodiversity in native and agricultural habitats. Conservation Biology 15:378-388.

SCHULZE, C. H. \& FIEDLER, K. 2003. Hawkmoth diversity in Northern Borneo does not reflect the influence of anthropogenic habitat disturbance. Ecotropica 9:99-102.

SCHULZE, C. H., LINSENMAIR, K. E. \& FIEDLER, K. 2001. Understorey versus canopy - patterns of vertical stratification and diversity among Lepidoptera in a Bornean rain forest. Plant Ecology 153:133-152.

SHAHABUDDIN, G. \& TERBORGH, J. W. 1999. Frugivorous butterflies in Venezuelan forest fragments: abundance, diversity and the effects of isolation. Journal of Tropical Ecology 15:703-722.
SPALDING, A. \& PARSONS, M. 2004. Light trap transects as a field method for ascertaining the habitat preferences of night-flying Lepidoptera, using Mythimna turca (Linnaeus 1761) (Lepidoptera: Noctuidae) as an example. Journal of Insect Conservation 8:185-195. STORK, N. E., SRIVASTAVA, D. S., WATT, A. D. \& LARSEN, T. B. 2003. Butterfly diversity and silvicultural practice in lowland rainforests of Cameroon. Biodiversity and Conservation 12:387-410.

SUMMERVILLE, K. S. \& CRIST, T. O. 2003. Determinants of lepidopteran community composition and species diversity in eastern deciduous forests: roles of season, eco-region and patch size. Oikos 100:134148.

WILLOTT, S. J. 1999. The effects of selective logging on the distribution of moths in a Bornean rainforest. Philosophical Transactions of the Royal Society of London Series B-Biological Sciences 354:1783-1790.

WILSON, E. O. 1987. The little things that run the world (the importance and conservation of invertebrates). Conservation Biology 1:344-346.

YELA, J. L. \& HOLYOAK, M. 1997. Effects of moonlight and meteorological factors on light and bait trap catches of noctuid moths (Lepidoptera: Noctuidae). Environmental Entomology 26:12831290.

Appendix 1. Species list and abundances of Arctiidae, Saturniidae and Sphingidae from 30 nights of light-trapping at five primary forest (PF), five secondary forest (SF) and five Eucalyptus plantation (EUC) sites within the Jari landscape, northern Brazilian Amazonia. Code = label for species appearing in Figure 4.

\begin{tabular}{|c|c|c|c|c|c|}
\hline \multirow[b]{2}{*}{ Code } & \multirow[b]{2}{*}{ Species } & \multicolumn{3}{|c|}{ Number of individuals } & \multirow[b]{2}{*}{ Total } \\
\hline & & $\mathrm{PF}$ & SF & EUC & \\
\hline & Arctiidae & & & & \\
\hline & Agaraea semivitrea Rothschild,1909 & 1 & & 14 & 15 \\
\hline & Amaxia aff. affinis & & 2 & & 2 \\
\hline & Amaxia carinosa Schaus, 1920 & & 1 & 1 & 2 \\
\hline & Amaxia consistens Schaus, 1905 & 1 & & & 1 \\
\hline & Amaxia pardalis Walker, 1855 & & 1 & & 1 \\
\hline & Amaxia theon Druce, 1900 & & 2 & & 2 \\
\hline & Ammalo helops (Cramer, 1775) & & & 2 & 2 \\
\hline & Ammalo sp. 1 & & 1 & 4 & 5 \\
\hline & Aphyle cuneata Hampson, 1905 & 1 & & & 1 \\
\hline & Araeomolis irrupta (Schaus, 1905) & 1 & & & 1 \\
\hline \multirow[t]{18}{*}{ I } & Araeomolis rubens (Schaus 1905) & 19 & 1 & 2 & 22 \\
\hline & Ardonea sp. 1 & 2 & 1 & 2 & 5 \\
\hline & Ardonea sp. 2 & & 1 & & 1 \\
\hline & Azatrephes discalis (Walker, 1856) & 2 & & & 2 \\
\hline & Bertholdia sp. 1 & & 1 & & 1 \\
\hline & Cacostatia flaviventralis Dognin, 1909 & 1 & & & 1 \\
\hline & Calonotos sp. 1 & 2 & 2 & 1 & 5 \\
\hline & Carales sp. 1 & & & 1 & 1 \\
\hline & Carales astur (Cramer, 1777) & & & 1 & 1 \\
\hline & Castrica phalaenoides (Drury, 1773) & & & 1 & 1 \\
\hline & Coiffaitarctia ockenderi (Rothschild, 1909) & 3 & & & 3 \\
\hline & Cratoplastis rectiradia (Hampson, 1901) & & 1 & & 1 \\
\hline & Cresera affinis (Rothschild, 1909) & 3 & & 1 & 4 \\
\hline & Cresera hieroglyphica (Schaus, 1905) & 1 & & & 1 \\
\hline & Cresera ilus (Cramer, 1776) & & 1 & & 1 \\
\hline & Dysschema aff. tricolor & & 1 & & 1 \\
\hline & Elysius conspersus Walker, 1855 & & 1 & 1 & 2 \\
\hline & Epidesma ursula (Cramer, 1782) & & & 2 & 2 \\
\hline \multirow[t]{5}{*}{$\mathrm{V}$} & Eriostepta albiscripta (Schaus, 1905) & 6 & 1 & & 7 \\
\hline & Eriostepta fulvescens Rothschild, 1909 & & & 1 & 1 \\
\hline & Ernassa nr. sanguinolenta & & 1 & & 1 \\
\hline & Eucyrta albicollis Felder, 1874 & 1 & & & 1 \\
\hline & Eupseudosoma aberrans Schaus, 1905 & & 4 & 10 & 14 \\
\hline
\end{tabular}


Appendix 1. Continued

\begin{tabular}{|c|c|c|c|c|c|}
\hline \multirow[b]{2}{*}{ Code } & \multirow[b]{2}{*}{ Species } & \multicolumn{3}{|c|}{ Number of individuals } & \multirow[b]{2}{*}{ Total } \\
\hline & & $\mathrm{PF}$ & $\mathrm{SF}$ & EUC & \\
\hline & Eupseudosoma involuta (Sepp, 1855) & 2 & 5 & 22 & 29 \\
\hline & Eupseudosoma larissa (Druce, 1890) & & 1 & 1 & 2 \\
\hline & Eupseudosoma sp. 1 & & & 1 & 1 \\
\hline \multirow[t]{59}{*}{ A } & Evius albicoxae (Schaus 1905) & 108 & 9 & 18 & 135 \\
\hline & Evius hippia (Stoll, 1790) & & & 1 & 1 \\
\hline & Evius sp. 1 & & 1 & & 1 \\
\hline & Gorgonidia buckleyi (Druce, 1883) & 1 & & 1 & 2 \\
\hline & Gorgonidia sp. 1 & & 1 & & 1 \\
\hline & Haemanota improvisa (Dognin, 1923) & 3 & & & 3 \\
\hline & Halysidota interlineata Walker, 1855 & & 1 & 2 & 3 \\
\hline & Halysidota sannionis (Rothschild, 1909) & & & 1 & 1 \\
\hline & Halysidota sp. 1 & & & 2 & 2 \\
\hline & Halysidota sp. 2 & & & 2 & 2 \\
\hline & Halysidota sp. 3 & & & 1 & 1 \\
\hline & Halysidota sp. 4 & & & 1 & 1 \\
\hline & Heliura sp. 1 & 1 & 1 & 4 & 6 \\
\hline & Homoeocera stictosoma Druce, 1898 & & & 1 & 1 \\
\hline & Hyalurga aff. fenestra & 1 & & & 1 \\
\hline & Hypercompe alpha (Oberthür, 1881) & & & 35 & 35 \\
\hline & Hypercompe sp. 1 & & & 1 & 1 \\
\hline & Hypercompe sp. 2 & & & 1 & 1 \\
\hline & Hypercompe sp. 3 & & & 8 & 8 \\
\hline & Hypercompe sp. 4 & & & 3 & 3 \\
\hline & Hypercompe sp. 5 & & & 3 & 3 \\
\hline & Hypercompe sp. 6 & & & 7 & 7 \\
\hline & Hypercompe sp. 7 & & & 5 & 5 \\
\hline & Hypercompe sp. 8 & & & 1 & 1 \\
\hline & Hypercompe sp. 9 & & & 1 & 1 \\
\hline & Hypercompe sp. 10 & & 1 & 1 & 2 \\
\hline & Hypocrita calida (Felder, 1874) & & 4 & 2 & 6 \\
\hline & Hypocrita excellens (Walker, 1854) & & 1 & & 1 \\
\hline & Hypocrita sp. 1 & & 3 & & 3 \\
\hline & Hyponerita aff. tipolis & 3 & 1 & 1 & 5 \\
\hline & Hyponerita declivis Schaus, 1905 & & 1 & & 1 \\
\hline & Hyponerita tipolis (Druce, 1896) & 1 & & & 1 \\
\hline & Idalus admirabilis (Cramer, 1777) & 1 & 15 & 45 & 61 \\
\hline & Idalus aleteria (Schaus, 1905) & 3 & 5 & 4 & 12 \\
\hline & Idalus metacrinis (Rothschild, 1909) & & & 1 & 1 \\
\hline & Idalus nigropunctata (Rothschild, 1909) & 1 & & & 1 \\
\hline & Ischnognatha semiopalina Felder, 1874 & 1 & & & 1 \\
\hline & Lepidokirbyia sp. 1 & 1 & & & 1 \\
\hline & Lepidokirbyia vittipes (Walker, 1855) & & 4 & 1 & 5 \\
\hline & Lophocampa pectina (Schaus, 1896) & & & 3 & 3 \\
\hline & Lophocampa sp. 1 & 1 & & & 1 \\
\hline & Lophocampa sp. 2 & 1 & & & 1 \\
\hline & Lophocampa sp. 3 & & & 1 & 1 \\
\hline & Lophocampa sp. 4 & 1 & & 1 & 2 \\
\hline & Lophocampa sp. 5 & 1 & 2 & 1 & 4 \\
\hline & Lophocampa sp. 6 & & & 2 & 2 \\
\hline & Machaeraptenus crocopera (Schaus, 1905) & 1 & & & 1 \\
\hline & Melese drucei Rothschild, 1909 & 2 & 3 & 2 & 7 \\
\hline & Melese sp. 1 & & 1 & & 1 \\
\hline & Neonerita dorsipuncta Hampson, 1901 & & 1 & & 1 \\
\hline & Neritos aff. cardinalis & 1 & & & 1 \\
\hline & Neritos sorex Druce, 1902 & 1 & & & 1 \\
\hline & Orcynia calcarata (Walker, 1854) & & & 3 & 3 \\
\hline & Ormetica aff. contraria & & 1 & & 1 \\
\hline & Ormetica sp. 1 & & & 1 & 1 \\
\hline & Ormetica sp. 2 & & 4 & 1 & 5 \\
\hline & Ormetica sphingidea (Perty, 1833) & 1 & 3 & 12 & 16 \\
\hline & Parathyris cedonulli (Stoll, 1781) & & & 1 & 1 \\
\hline & Parevia aff. parnelli & & 1 & & 1 \\
\hline
\end{tabular}


Appendix 1. Continued

\begin{tabular}{|c|c|c|c|c|c|}
\hline \multirow[b]{2}{*}{ Code } & \multirow[b]{2}{*}{ Species } & \multicolumn{3}{|c|}{ Number of individuals } & \multirow[b]{2}{*}{ Total } \\
\hline & & $\mathrm{PF}$ & SF & EUC & \\
\hline & Parevia sp. 1 & & 1 & & 1 \\
\hline & Phaeomolis sp. 1 & 2 & & & 2 \\
\hline & Premolis semirufa (Walker, 1856) & 4 & & & 4 \\
\hline & Pseudalus aurantiacus Rothschild, 1909 & & 3 & & 3 \\
\hline & Psychophasma erosa (Herrich-Schäffer, 1858) & 1 & 1 & 1 & 3 \\
\hline & Robinsonia fogra Schaus, 1895 & 1 & 1 & 1 & 3 \\
\hline & Trichromia androconiata (Rothschild, 1909) & 1 & 1 & & 2 \\
\hline & Trichromia complicata (Schaus, 1905) & 1 & & & 1 \\
\hline \multirow[t]{2}{*}{ K } & Trichromia onytes (Cramer 1777) & 15 & 1 & 2 & 18 \\
\hline & Trichromia persimilis (Rothschild, 1909) & 2 & 1 & 1 & 4 \\
\hline \multirow[t]{2}{*}{$\mathrm{E}$} & Virbia satara Seitz, 1919 & 34 & 2 & 9 & 45 \\
\hline & Virbia sp. 1 & 1 & & & 1 \\
\hline \multirow[t]{29}{*}{$\mathrm{Y}$} & Virbia sp. 2 & 5 & 2 & & 7 \\
\hline & Viviennea gyrata (Schaus, 1920) & & & 1 & 1 \\
\hline & Zatrephes aff. variegata & & & 1 & 1 \\
\hline & Zatrephes sp. 1 & 1 & & & 1 \\
\hline & Arctiidae sp. 1 & 1 & & & 1 \\
\hline & Arctiidae sp. 2 & 1 & & & 1 \\
\hline & Arctiidae sp. 3 & & & 3 & 3 \\
\hline & Arctiidae sp. 4 & & & 3 & 3 \\
\hline & Arctiidae sp. 5 & 2 & & 2 & 4 \\
\hline & Arctiidae sp. 6 & & 1 & 1 & 2 \\
\hline & Arctiidae sp. 7 & & & 2 & 2 \\
\hline & Arctiidae sp. 8 & 1 & & & 1 \\
\hline & Arctiidae sp. 9 & & & 1 & 1 \\
\hline & Arctiidae sp. 10 & & & 1 & 1 \\
\hline & Arctiidae sp. 11 & 1 & & & 1 \\
\hline & Arctiidae sp. 12 & & 1 & & 1 \\
\hline & Arctiidae sp. 13 & 2 & & 1 & 3 \\
\hline & Arctiidae sp. 14 & 3 & & & 3 \\
\hline & Arctiidae sp. 15 & 2 & 1 & 1 & 4 \\
\hline & Arctiidae sp. 16 & & & 2 & 2 \\
\hline & Arctiidae sp. 17 & 1 & 2 & & 3 \\
\hline & Arctiidae sp. 18 & & 1 & & 1 \\
\hline & Arctiidae sp. 19 & & & 2 & 2 \\
\hline & Arctiidae sp. 20 & & 1 & & 1 \\
\hline & Arctiidae sp. 21 & & 1 & & 1 \\
\hline & Arctiidae sp. 22 & & & 1 & 1 \\
\hline & Arctiidae sp. 23 & & & 1 & 1 \\
\hline & Arctiidae sp. 24 & 1 & & 1 & 2 \\
\hline & Arctiidae sp. 25 & & 1 & & 1 \\
\hline \multirow[t]{21}{*}{$\mathrm{T}$} & Arctiidae sp. 26 & 7 & 3 & 5 & 15 \\
\hline & Arctiidae sp. 27 & 2 & & & 2 \\
\hline & Arctiidae sp. 28 & 1 & & & 1 \\
\hline & Arctiidae sp. 29 & 1 & & & 1 \\
\hline & Arctiidae sp. 30 & 1 & & & 1 \\
\hline & Arctiidae sp. 31 & & & 1 & 1 \\
\hline & Arctiidae sp. 32 & & & 12 & 12 \\
\hline & Arctiidae sp. 33 & 1 & & 7 & 8 \\
\hline & Arctiidae sp. 34 & & 3 & 4 & 7 \\
\hline & Arctiidae sp. 35 & & 1 & 1 & 2 \\
\hline & Arctiidae sp. 36 & & & 2 & 2 \\
\hline & Arctiidae sp. 37 & 4 & 3 & 8 & 15 \\
\hline & Arctiidae sp. 38 & & 1 & 1 & 2 \\
\hline & Arctiidae sp. 39 & 1 & & 1 & 2 \\
\hline & Arctiidae sp. 40 & & 2 & & 2 \\
\hline & Arctiidae sp. 41 & 1 & & & 1 \\
\hline & Arctiidae sp. 42 & 5 & 1 & & 6 \\
\hline & Arctiidae sp. 43 & 1 & 14 & 2 & 17 \\
\hline & Arctiidae sp. 44 & & 7 & 1 & 8 \\
\hline & Arctiidae sp. 45 & & & 1 & 1 \\
\hline & Arctiidae sp. 46 & & & 1 & 1 \\
\hline
\end{tabular}


Appendix 1. Continued

\begin{tabular}{|c|c|c|c|c|c|}
\hline \multirow[b]{2}{*}{ Code } & \multirow[b]{2}{*}{ Species } & \multicolumn{3}{|c|}{ Number of individuals } & \multirow[b]{2}{*}{ Total } \\
\hline & & $\mathrm{PF}$ & SF & EUC & \\
\hline & Arctiidae sp. 47 & & & 1 & 1 \\
\hline & Arctiidae sp. 48 & & 1 & & 1 \\
\hline & Arctiidae sp. 49 & & & 1 & 1 \\
\hline & Arctiidae sp. 50 & & 4 & & 4 \\
\hline & Arctiidae sp. 51 & & 2 & & 2 \\
\hline & Arctiidae sp. 52 & 5 & & & 5 \\
\hline & Arctiidae sp. 53 & 1 & & & 1 \\
\hline & Arctiidae sp. 54 & & 2 & 1 & 3 \\
\hline & Arctiidae sp. 55 & 2 & 5 & 19 & 26 \\
\hline & Arctiidae sp. 56 & & & 4 & 4 \\
\hline & Arctiidae sp. 57 & & & 1 & 1 \\
\hline & Arctiidae sp. 58 & 1 & & & 1 \\
\hline & Arctiidae sp. 59 & 2 & & & 2 \\
\hline & Arctiidae sp. 60 & & & 3 & 3 \\
\hline & Arctiidae sp. 61 & & & 10 & 10 \\
\hline & Arctiidae sp. 62 & & & 4 & 4 \\
\hline & Arctiidae sp. 63 & & & 1 & 1 \\
\hline & Arctiidae sp. 64 & 1 & & & 1 \\
\hline & Arctiidae sp. 65 & & 1 & 23 & 24 \\
\hline & Arctiidae sp. 66 & & 2 & 1 & 3 \\
\hline & Arctiidae sp. 67 & 1 & & & 1 \\
\hline & Arctiidae sp. 68 & 1 & & & 1 \\
\hline & Arctiidae sp. 69 & & 2 & & 2 \\
\hline & Arctiidae sp. 70 & & & 1 & 1 \\
\hline & Arctiidae sp. 71 & & & 1 & 1 \\
\hline & Arctiidae sp. 72 & & & 3 & 3 \\
\hline $\mathrm{L}$ & Arctiidae sp. 73 & 14 & 2 & 2 & 18 \\
\hline \multirow[t]{35}{*}{$\mathrm{P}$} & Arctiidae sp. 74 & 10 & 1 & 3 & 14 \\
\hline & Arctiidae sp. 75 & & & 1 & 1 \\
\hline & Arctiidae sp. 76 & 1 & 1 & & 2 \\
\hline & Arctiidae sp. 77 & & & 2 & 2 \\
\hline & Arctiidae sp. 78 & & & 1 & 1 \\
\hline & Arctiidae sp. 79 & & & 1 & 1 \\
\hline & Arctiidae sp. 80 & & & 1 & 1 \\
\hline & Arctiidae sp. 81 & 1 & & & 1 \\
\hline & Arctiidae sp. 82 & 1 & & & 1 \\
\hline & Arctiidae sp. 83 & & & 1 & 1 \\
\hline & Arctiidae sp. 84 & 2 & & & 2 \\
\hline & Arctiidae sp. 85 & 1 & & & 1 \\
\hline & Arctiidae sp. 86 & & & 1 & 1 \\
\hline & Arctiidae sp. 87 & & 1 & & 1 \\
\hline & Arctiidae sp. 88 & & & 1 & 1 \\
\hline & Arctiidae sp. 89 & & & 1 & 1 \\
\hline & Arctiidae sp. 90 & & 5 & 1 & 6 \\
\hline & Arctiidae sp. 91 & & 1 & & 1 \\
\hline & Arctiidae sp. 92 & & 1 & & 1 \\
\hline & Arctiidae sp. 93 & 1 & & & 1 \\
\hline & Arctiidae sp. 94 & 1 & & & 1 \\
\hline & Arctiidae sp. 95 & & & 1 & 1 \\
\hline & Arctiidae sp. 96 & & & 1 & 1 \\
\hline & Arctiidae sp. 97 & & & 1 & 1 \\
\hline & Arctiidae sp. 98 & 1 & & & 1 \\
\hline & Arctiidae sp. 99 & & & 1 & 1 \\
\hline & Arctiidae sp. 100 & & 1 & & 1 \\
\hline & Arctiidae sp. 101 & & & 1 & 1 \\
\hline & Arctiidae sp. 102 & & 1 & & 1 \\
\hline & Arctiidae sp. 103 & & & 1 & 1 \\
\hline & Arctiidae sp. 104 & & & 1 & 1 \\
\hline & Arctiidae sp. 105 & & 1 & & 1 \\
\hline & Arctiidae sp. 106 & & & 1 & 1 \\
\hline & Arctiidae sp. 107 & 1 & & & 1 \\
\hline & Arctiidae sp. 108 & 1 & & & 1 \\
\hline
\end{tabular}


Appendix 1. Continued

\begin{tabular}{|c|c|c|c|c|c|}
\hline \multirow[b]{2}{*}{ Code } & \multirow[b]{2}{*}{ Species } & \multicolumn{3}{|c|}{ Number of individuals } & \multirow[b]{2}{*}{ Total } \\
\hline & & $\mathrm{PF}$ & SF & $\overline{\text { EUC }}$ & \\
\hline & Arctiidae sp. 109 & 1 & & & 1 \\
\hline & Arctiidae sp. 110 & 1 & & & 1 \\
\hline & Arctiidae sp. 111 & & & 1 & 1 \\
\hline & Arctiidae sp. 112 & 1 & & & 1 \\
\hline & Arctiidae sp. 113 & 1 & & & 1 \\
\hline & Arctiidae sp. 114 & 1 & & & 1 \\
\hline & Arctiidae sp. 115 & 1 & & & 1 \\
\hline & Arctiidae sp. 116 & & & 1 & 1 \\
\hline & Arctiidae sp. 117 & 2 & & 2 & 4 \\
\hline & Arctiidae sp. 118 & 1 & & 2 & 3 \\
\hline & Arctiidae sp. 119 & & 1 & 1 & 2 \\
\hline & Arctiidae sp. 120 & 1 & 1 & & 2 \\
\hline & & 348 & 186 & 440 & 974 \\
\hline & Saturniidae & & & & \\
\hline & Adeloneivaia boisduvalii (Doumet, 1859) & 1 & 6 & & 7 \\
\hline & Adeloneivaia catoxantha (Rothschild, 1907) & & 3 & & 3 \\
\hline $\mathrm{U}$ & Adeloneivaia jason (Boisduval, 1872) & 6 & 2 & 7 & 15 \\
\hline \multirow[t]{2}{*}{$\mathrm{C}$} & Adeloneivaia subangulata (Herrich-Schäffer, 1855) & 36 & 12 & & 48 \\
\hline & Ancistrota plagia (Hübner, 1815) & 2 & 7 & 15 & 24 \\
\hline \multirow[t]{10}{*}{$\mathrm{N}$} & Arsenura armida (Cramer, 1780) & 12 & 1 & 2 & 15 \\
\hline & Arsenura batesii (Felder, 1874) & 2 & 1 & & 3 \\
\hline & Arsenura ponderosa Rothschild, 1907 & 3 & & & 3 \\
\hline & Automerina caudatula (Felder, 1874) & 1 & & & 1 \\
\hline & Automerina cypria (Gmelin, 1788) & & 6 & & 6 \\
\hline & Automeris bilinea (Walker, 1855) & 1 & & & 1 \\
\hline & Automeris curvilinea Schaus, 1906 & & 1 & & 1 \\
\hline & Automeris gabriellae Lemaire, 1966 & & & 1 & 1 \\
\hline & Automeris hamata Schaus, 1906 & & & 1 & 1 \\
\hline & Automeris liberia (Cramer, 1780) & & 11 & 62 & 73 \\
\hline $\mathrm{D}$ & Automeris midea Maasen \& Weymer, 1886 & 34 & 1 & & 35 \\
\hline \multirow[t]{8}{*}{ Q } & Automeris moresca Schaus, 1906 & 9 & 5 & 1 & 15 \\
\hline & Automeris sp. 1 & 1 & & & 1 \\
\hline & Cerodirphia apunctata Dias \& Lemaire, 1991 & 1 & 1 & & 2 \\
\hline & Citheronia hamifera Rothschild, 1907) & 2 & & & 2 \\
\hline & Citheronia phoronea (Cramer, 1779) & & 1 & & 1 \\
\hline & Citheronia sp. 1 & & 1 & & 1 \\
\hline & Copaxa decrescens (Walker, 1855) & 2 & & & 2 \\
\hline & Copiopteryx jehovah (Strecker, 1874) & 1 & & & 1 \\
\hline \multirow[t]{6}{*}{$\mathrm{X}$} & Copiopteryx semiramis (Cramer, 1775) & 5 & 1 & 1 & 7 \\
\hline & Dirphia acidalia Hübner, 1819 & & 1 & & 1 \\
\hline & Dirphia tarquinia (Cramer, 1775) & 1 & 17 & & 18 \\
\hline & Eacles adoxa Jordan, 1910 & 2 & & & 2 \\
\hline & Eacles barnesi Schaus, 1905 & & & 2 & 2 \\
\hline & Eacles guianensis Schaus, 1905 & 1 & & & 1 \\
\hline \multirow[t]{2}{*}{$\mathrm{O}$} & Eacles imperialis (Drury, 1773) & 11 & 1 & 15 & 27 \\
\hline & Eacles ormondei Schaus, 1889 & & & 2 & 2 \\
\hline \multirow[t]{14}{*}{ G } & Eacles penelope (Cramer, 1775) & 22 & 6 & 74 & 102 \\
\hline & Gamelia abas(Cramer, 1775) & 1 & 1 & & 2 \\
\hline & Gamelia rubriluna (Walker, 1862) & & 1 & & 1 \\
\hline & Gamelia sp. 1 & & & 1 & 1 \\
\hline & Hylesia annulata Schaus, 1911 & 1 & 4 & 1 & 6 \\
\hline & Hylesia cottica Schaus, 1932 & & & 1 & 1 \\
\hline & Hylesia metabus (Cramer, 1776) & 1 & & 2 & 3 \\
\hline & Hylesia murex Dyar, 1913 & & 1 & & 1 \\
\hline & Hylesia obtusa Dognin, 1923 & & & 2 & 2 \\
\hline & Hylesia sp. 1 & 4 & & 1 & 5 \\
\hline & Hylesia sp. 2 & & 2 & & 2 \\
\hline & Hylesia sp. 3 & & & 1 & 1 \\
\hline & Hyperchiria aniris (Jordan, 1910) & 1 & & & 1 \\
\hline & Hyperchiria nausica (Cramer, 1779) & 3 & 5 & 4 & 12 \\
\hline \multirow[t]{2}{*}{ W } & Molippa placida (Schaus, 1921) & 6 & 4 & 1 & 11 \\
\hline & Molippa simillima Jones, 1907 & 3 & 1 & 1 & 5 \\
\hline
\end{tabular}


Appendix 1. Continued

\begin{tabular}{|c|c|c|c|c|c|}
\hline \multirow[b]{2}{*}{ Code } & \multirow[b]{2}{*}{ Species } & \multicolumn{3}{|c|}{ Number of individuals } & \multirow[b]{2}{*}{ Tota } \\
\hline & & $\mathrm{PF}$ & SF & EUC & \\
\hline$\overline{\mathrm{F}}$ & Othorene hodeva (Druce, 1904) & 27 & 6 & 1 & 34 \\
\hline $\mathrm{B}$ & Othorene purpurascens (Schaus, 1905) & 38 & 11 & 6 & 55 \\
\hline \multirow[t]{7}{*}{$\mathrm{H}$} & Paradaemonia platydesmia (Rothschild, 1907) & 22 & & 1 & 23 \\
\hline & Periga angulosa (Lemaire, 1971) & & & 1 & 1 \\
\hline & Periga cynira (Cramer, 1777) & 6 & 19 & 3 & 28 \\
\hline & Periphoba hircia (Cramer, 1775) & 3 & 12 & 38 & 53 \\
\hline & Pseudautomeris irene (Cramer, 1779) & 1 & & & 1 \\
\hline & Pseudautomeris lata (Conte, 1906) & & 1 & & 1 \\
\hline & Pseudautomeris salmonea (Cramer, 1777) & & & 1 & 1 \\
\hline $\mathrm{R}$ & Pseudodirphia obliqua (Bouvier, 1924) & 7 & 10 & 7 & 24 \\
\hline M & Psilopygoides oda (Schaus, 1905) & 13 & & & 13 \\
\hline$S$ & Ptiloscola photophila (Rothschild, 1907) & 6 & 12 & 4 & 22 \\
\hline \multirow[t]{48}{*}{$\mathrm{J}$} & Rhescyntis hermes (Rothschild, 1907) & 17 & & & 17 \\
\hline & Rhescyntis hippodamia (Cramer, 1777) & 2 & 1 & & 3 \\
\hline & Syssphinx molina (Cramer, 1780) & 2 & 8 & 4 & 14 \\
\hline & Titaea tamerlan (Maasen, 1869) & 2 & 1 & & 3 \\
\hline & Titaea timur (Fassl, 1915) & & 1 & & 1 \\
\hline & & 322 & 186 & 264 & 772 \\
\hline & Sphingidae & & & & \\
\hline & Adhemarius daphne (Boisduval, 1875) & & & 1 & 1 \\
\hline & Adhemarius palmeri (Boisduval, 1875) & 1 & & & 1 \\
\hline & Aellopos fadus (Cramer, 1775) & & 1 & 1 & 2 \\
\hline & Aellopos titan (Cramer, 1777) & & & 1 & 1 \\
\hline & Aleuron iphis (Walker, 1856) & & 1 & & 1 \\
\hline & Aleuron neglectum Rothschild \& Jordan, 1903 & & 1 & & 1 \\
\hline & Callionima pan (Cramer, 1779) & & 1 & & 1 \\
\hline & Callionima parce (Fabricius, 1775) & & & 2 & 2 \\
\hline & Enyo gorgon (Cramer, 1777) & & & 2 & 2 \\
\hline & Enyo lugubris (Linneaus, 1771) & & & 3 & 3 \\
\hline & Enyo ocypete (Linneaus, 1758) & & & 1 & 1 \\
\hline & Erinnyis alope (Drury, 1773) & & & 1 & 1 \\
\hline & Erinnyis ello (Linneaus, 1758) & & & 15 & 15 \\
\hline & Erinnyis lassauxii (Boisduval, 1859) & & & 1 & 1 \\
\hline & Erinnyis obscura (Fabricius, 1775) & & & 1 & 1 \\
\hline & Eumorpha capronnieri (Boisduval, 1875) & & & 1 & 1 \\
\hline & Manduca diffissa (Butler, 1871) & & & 3 & 3 \\
\hline & Manduca florestan (Stoll, 1782) & 1 & & 2 & 3 \\
\hline & Manduca lucetius (Cramer, 1780) & & 1 & 12 & 13 \\
\hline & Manduca occulta (Rothschild \& Jordan, 1903) & & & 1 & 1 \\
\hline & Manduca rustica (Fabricius, 1775) & & & 1 & 1 \\
\hline & Nyceryx coffaeae (Walker, 1856) & & 1 & & 1 \\
\hline & Nyceryx riscus (Schaus, 1890) & & & 1 & 1 \\
\hline & Pachylia ficus (Linneaus, 1758) & & & 1 & 1 \\
\hline & Perigonia ilus Boisduval, 1870 & & & 11 & 11 \\
\hline & Perigonia lusca (Fabricius, 1777) & & & 1 & 1 \\
\hline & Perigonia passerina Boisduval, 1875 & & & 2 & 2 \\
\hline & Protambulyx goeldii Rothschild \& Jordan, 1903 & & & 1 & 1 \\
\hline & Protambulyx strigilis (Linneaus, 1771) & & 1 & & 1 \\
\hline & Xylophanes anubus (Cramer, 1777) & & & 1 & 1 \\
\hline & Xylophanes chiron (Drury, 1771) & & & 1 & 1 \\
\hline & Xylophanes elara (Druce, 1878) & 1 & & & 1 \\
\hline & Xylophanes epaphus (Boisduval, 1875) & 3 & & & 3 \\
\hline & Xylophanes guianensis (Rothschild, 1894) & & 3 & 1 & 4 \\
\hline & Xylophanes loelia (Druce, 1878) & & & 1 & 1 \\
\hline & Xylophanes neoptolemus (Cramer, 1780) & & & 5 & 5 \\
\hline & Xylophanes rufescens (Rothschild, 1894) & 1 & & & 1 \\
\hline & Xylophanes tersa (Linneaus, 1771) & & 1 & 8 & 9 \\
\hline & Xylophanes titana (Druce, 1878) & & 1 & & 1 \\
\hline & & 7 & 12 & 83 & 102 \\
\hline & Total & 677 & 384 & 787 & 1848 \\
\hline
\end{tabular}

